Board of Governors of the Federal Reserve System

International Finance Discussion Papers

Number 723

April 2002

INTERNATIONAL COORDINATION OF MACROECONOMIC POLICIES: STILL ALIVE IN THE NEW MILLENNIUM?

Laurence H. Meyer, Brian M. Doyle, Joseph E. Gagnon and Dale W. Henderson

NOTE: International Finance Discussion Papers are preliminary materials circulated to stimulate discussion and critical comment. References in publications to International Finance Discussion Papers (other than an acknowledgment that the writer has had access to unpublished material) should be cleared with the author or authors. Recent IFDPs are available on the Web at www.federalreserve.gov/pubs/ifdp/. 


\title{
INTERNATIONAL COORDINATION OF MACROECONOMIC POLICIES: STILL ALIVE IN THE NEW MILLENNIUM?
}

\author{
Laurence H. Meyer, Brian M. Doyle, Joseph E. Gagnon and Dale W. Henderson*
}

\begin{abstract}
In this paper we provide two building blocks for an analysis of international policy coordination: (1) a survey of models of policy coordination, and (2) an account of experience with policy coordination among the G-7 countries and within Europe since the breakdown of the Bretton Woods System. Using these building blocks, we investigate the correspondence between the models and experience and attempt to draw lessons for both the modelers and the practitioners. We find that the correspondence is close enough that the models help in analyzing several instances of actual policy coordination, but that the correspondence could be even closer. As for lessons for modelers, we suggest that they devote more attention to the analysis of information exchange, a key feature of practical policy coordination; to the coordination of different types of policies; to the ramifications of political divisions within countries; and to the implications of market irrationality and speculative bubbles. As for lessons for policy makers, we suggest that they give more consideration to the choice of their ultimate objectives, in particular to whether the current account should always be close to balance; to achieving better internal policies; and to the greater use of fiscal policy as a stabilization tool.
\end{abstract}

Keywords: international policy coordination, cooperation, information exchange, monetary policy, fiscal policy, G-7, European economic and monetary union.

* This version of the paper is essentially unchanged from the one that was prepared for and presented at the end-of-program conference of the Global Economic Institutions Programme, entitled "Reforming the Architecture of Global Economic Institutions" and held at the Bank of England on May 5-6, 2000. As such, it reflects only developments, both in the research and in the practice of international policy coordination, up to that date. At the time this paper was written, Meyer was a Governor of the Federal Reserve System. Doyle, Gagnon, and Henderson are staff economists in the Division of International Finance at the Federal Reserve Board. The authors thank Ralph Bryant, C. Randall Henning, Andrew Hughes-Hallet, Karen Johnson, Steven Kamin, Peter Kenen, James Lister, Ellen Meade, Louellen Stedman, and Edwin Truman for helpful comments and advice. The authors also thank Hayden Smith for research assistance. The views expressed in this paper are solely the responsibility of the authors and should not be interpreted as reflecting those of the Board of Governors of the Federal Reserve System or any other person associated with the Federal Reserve System. 


\section{Introduction}

The subject of this paper is macroeconomic policy coordination among developed countries. ${ }^{1}$ The paper covers both the findings of theoretical models of policy coordination and the historical experience of coordination between policy makers in different countries. ${ }^{2}$ Most importantly, the paper assesses the extent to which models of policy coordination capture the key features of practical experience. For areas where the models and experience diverge, we attempt to draw some lessons for both modelers and policy makers.

The past few decades have seen the development of theoretical and empirical models designed to explore the benefits of international macroeconomic policy coordination. The models highlight the fact that macroeconomic policy actions in one country affect economic welfare in other countries; that is, they have externalities for other countries. The key insight of the models is that coordination of policies among countries that takes into account these externalities may lead to higher welfare for all countries. Starting with this key insight, the modeling of international policy coordination has moved in many different directions addressing such issues as the types of problems that coordination is best suited to address, which policies are best suited to address which problems, the means of enforcing international agreements, the roles that uncertainty and information sharing play in the coordination process, and the measurement of the gains from policy coordination.

The decades since the breakdown of the Bretton Woods system have witnessed a proliferation of attempts to discuss and coordinate macroeconomic policies among the major industrial nations and within Europe. Informal discussions in the early 1970s among a few finance ministers have evolved into regular meetings, involving several layers of leadership, in what are now referred to as the G-7 countries. These meetings have led to such high-profile international agreements as the Plaza Agreement of September 1985 and the Louvre Accord of February 1987. As well, discussions among economic policy makers take place on a regular basis at the Bank for International

${ }^{1}$ Therefore, there is no discussion of the theoretical and practical considerations raised by recent attempts to coordinate both the management of the financial crises in emerging markets and the design of an international financial system in which such crises occur less frequently and have less serious effects.

${ }^{2}$ The terms "cooperation" and "coordination" are used in different ways in different analyses of interactions among macroeconomic policy makers. In this paper, we use "cooperation" to refer to an agreement among policy makers in two or more nations that involves achieving a Pareto efficient outcome and that is credibly enforced, for example, by a supranational authority. In cases in which there is a set of two or more selfenforcing equilibria, we use "coordination" to refer to an attempt to achieve one particular equilibrium out of the set. These uses follow the conventions of game theory. Otherwise, we use "coordination" as a general term to refer to attempts by policy makers to achieve improved outcomes. 
Settlements (BIS), the International Monetary Fund (IMF), the Organization for Economic Cooperation and Development (OECD), and in numerous regional entities. While such meetings generally do not lead to formal agreements on coordinated macroeconomic policies, the exchange of information and views that takes place on these occasions is considered an important vehicle for enhancing the quality of economic policymaking among participating nations. Within Europe, an even more formalized process has led to the adoption of a common monetary policy for eleven countries in the EU, with explicit rules limiting fiscal policy independence as well.

There are several good surveys of models of policy coordination and many worthwhile discussions of the experience with policy coordination. However, there have been very few investigations of the correspondence between the models and experience. ${ }^{3}$ The main contributions of this paper are a further investigation of the correspondence and an attempt to draw lessons for both the modelers and practitioners of policy coordination.

Has the practical experience of international policy coordination generated the gains suggested by the models? From this perspective, it is the practical process of international policy cooperation that is put under the magnifying glass, and we consider what types of obstacles might be operating to prevent this process from achieving its hypothetical potential.

To what extent have the models captured the most salient aspects of macroeconomic policy coordination in practice? In this context, a disconnect between models and practice represents a failure of the modelers to properly specify the objectives and constraints facing policy makers.

The remainder of the paper is divided into three sections. First, there is a review of the theory of policy coordination. This section includes an attempt to summarize the contributions of some of the papers produced before this conference in connection with the Global Economic Institutions (GEI) project. Then, there is a discussion of the experience with policy coordination since the breakdown of the Bretton Woods System, both among G-7 countries and within Europe. Finally, there is an attempt to draw lessons based on both theory and experience. There are three appendices: one contains support for a proposition in the text, another contains a chronology of major events in the history of policy coordination, and the third provides a list of some regular international policy coordination meetings.

\section{Models of Policy Coordination}

In theory, international policy coordination raises welfare for all countries. Each country is concerned only with its own welfare. However, policy actions of each country affect the welfare of others; that is, they generate "externalities." Externalities give rise to policy conflicts. Each country would like the others to take policy actions different

\footnotetext{
${ }^{3}$ One very useful investigation is Bryant (1995).
} 
from those dictated by pure self-interest. Without coordination, these policy conflicts lead to (Pareto) inefficient outcomes, but with coordination, outcomes may be efficient.

\section{II.A A Canonical Example}

As an example, consider two symmetric countries, A and B, which face a symmetric negative productivity shock. With unchanged policies, this shock increases inflation in each country. Each country has an incentive to tighten monetary policy in order to lower inflation and raise welfare. However, tightening by one country causes its currency to appreciate thereby increasing inflation in the other country further. When one country takes an action that improves its own welfare and that action reduces the welfare of the other country, the country taking the action generates a negative externality for the other country. ${ }^{4}$ The policy conflict is that each country would like the other to expand not contract.

The payoffs for the two countries can be arrayed in a payoff matrix that has the same form as the payoff matrix for the well-known "prisoner's dilemma" game:

Country B

Tighten Less Tighten More

\begin{tabular}{cccc}
\multirow{2}{*}{ Country A } & Tighten Less & 3,3 & 0,4 \\
& Tighten More & 4,0 & 1,1
\end{tabular}

The first number in any pair is the payoff to country A. If A thinks that B is going to tighten less, A has an incentive to tighten more, get a payoff of 4, and leave B with a payoff of 0 and vice versa. For each country, Tighten More is a "dominant strategy" because it generates a larger payoff no matter what the other country does. If each country plays its dominant strategy, the outcome is the Nash equilibrium in which both countries receive payoffs of 1 . The Nash equilibrium is clearly inefficient. In the Nash equilibrium each country ignores the negative externality that it generates for the other, so each country adjusts its instrument by more than the amount consistent with efficiency. ${ }^{5}$

If the two countries could credibly commit to coordinate their policies, they could both choose Tighten Less and achieve the efficient outcome in which both would receive payoffs of 3 . However, each country has an incentive to renege on a commitment to choose Tighten Less. If one country assumes the other will choose Tighten Less, then it

\footnotetext{
${ }^{4}$ And if the action increases the welfare of the other country, the country taking the action generates a positive externality for the other country.

${ }^{5}$ And if the externalities were positive, each country would adjust its instrument by less than the amount consistent with efficiency.
} 
can do better by choosing Tighten More. In other words, a credible commitment to coordinate policies is not possible, so the efficient equilibrium is not achievable.

The simple productivity-shock game just considered is an example of a 'one-shot' game with complete information. Most of the basic elements of the analysis of international policy coordination and the refinements of this analysis can be illustrated by altering or relaxing the assumptions underlying this simple example. ${ }^{6}$ For simplicity, it is assumed throughout the discussion of the theory of policy coordination that the world economy consists of two symmetric countries.

\section{II.B Types of Policy Conflicts}

Policy conflicts that create an incentive for policy coordination are of two main types: stabilization conflicts and ongoing conflicts. Stabilization conflicts are temporary; they occur because of wage and price inertia and eventually disappear as wages and prices adjust. Stabilization conflicts can arise as a result of either disturbances or exogenous policy changes. Ongoing conflicts are permanent; they occur even if wages and prices are perfectly flexible and never disappear. Ongoing conflicts arise when countries have inconsistent objectives such as different desired values for the same bilateral current account or the same real exchange rate between two currencies.

\section{II.C Possible Causes of Stabilization Conflicts in Theory and Experience}

In theoretical analyses, it is usually assumed that stabilization conflicts arise because of exogenous shocks. Attention is usually focused on three basic configurations of shocks: symmetric shocks, (perfectly) asymmetric shocks, and country-specific shocks. $^{7}$ Symmetric shocks affect each of the two countries in exactly the same way; the example of equal negative productivity shocks in each of the two countries is considered above. Asymmetric shocks affect each of the two countries in equal and opposite ways. A country-specific shock affects one country and not the other. Stabilization conflicts for monetary policy can also arise because of initial conditions that one or more country regards as suboptimal and changes in fiscal policy that are driven by political or other non-stabilization considerations such that they are effectively exogenous. Suboptimal initial conditions and exogenous changes in fiscal policy can be divided into the same three configurations as purely exogenous shocks as described above.

Oil price shocks exemplify approximately symmetric shocks for most industrial countries. Inflation rates in Europe in the early 1980s can be thought of as symmetric

\footnotetext{
${ }^{6}$ See Hamada $(1974,1976,1979,1985)$ and Canzoneri and Henderson (1991) which contain the basic analysis and some refinements.

${ }^{7}$ The three basic configurations are not independent. A country-specific shock is the sum of pairs of symmetric and asymmetric shocks that are equal in absolute value. Nonetheless, dividing shocks into three configurations (instead of two) simplifies the exposition.
} 
suboptimal initial conditions. The simultaneous fiscal expansion in the United States and contraction in Europe and Japan in the early 1980s can be viewed as an asymmetric shock for monetary authorities. The upward movement in the dollar in early 1985 can be interpreted as having resulted from an asymmetric shock that raised the demand for dollar assets and lowered the demand for assets denominated in the other major currencies. Finally, German unification in the early 1990s and the Japanese asset bubble are good examples of country-specific shocks.

\section{II.D Commitment and Cooperation}

In the terminology of the policy coordination literature, efficient outcomes in oneshot games can be achieved through "cooperation". Cooperation involves commitments by two or more countries to follow efficient policies. Commitment is possible when there is a supranational authority that can punish departures from announced policies so severely that departures are unthinkable. If countries can commit themselves, they can act, in effect, as a single entity and choose their policies by joint maximization. That is, they can internalize the externalities that they generate for one another and achieve efficient outcomes. The threat of punishment causes each country to choose the efficient policy even though each country has an incentive to choose a policy other than its efficient policy if the other chooses its efficient policy.

In the special case of symmetric countries and symmetric shocks, efficient outcomes in monetary policy games can also be achieved by commitment to 'fixed exchange rate leadership' [Canzoneri and Gray (1985)]. One country commits to fix its money supply at the efficient value and the others agree to fix their exchange rates with that country. Of course, a common monetary policy is not optimal in the cases of asymmetric or country-specific shocks.

It may be difficult to convince countries to surrender their sovereignty to a supranational organization, so commitment and, therefore, the achievement of efficient outcomes through cooperation may not be possible. However, there are cases in which nations have surrendered some of their powers to supranational organizations with the intention of improving outcomes. In the area of trade relations, the General Agreement on Tariffs and Trade (GATT) and its successor the World Trade Organization (WTO) have had the power to punish deviations from agreed rules of behavior. In the area of monetary policy, the countries of the euro area have turned over the responsibility for setting monetary policy to the European Central Bank (ECB), so there is no need to consider the possibility of deviations and punishment. GATT, the WTO, and the ECB are all the result of formal agreements among nations.

\section{II.E Repeated Contact and Self Enforcing Agreements: Trigger Mechanisms}

Even if commitment is not possible, the fact that countries will face the same or a similar problem in the future may be enough to make it possible to achieve efficient outcomes. For example, if the game considered above is repeated every period, the countries may have different incentives than if the game is played only once. Suppose 
Country A plays "Tighten Less" in the first period and in every subsequent period as long as Country B has always played "Tighten Less". If Country B ever plays "Tighten More", then Country A plays "Tighten More" forever thereafter. If Country A follows this "trigger strategy" and B an analogous one, then both countries will play "Tighten Less" unless they discount the future "too much". The short-run benefits of cheating in one period by playing "Tighten More" when the other country plays "Tighten Less" are outweighed the costs of having both countries play "Tighten More" forever. Country A may play "Tighten Less" in each period because it believes that if it does so Country B will play "Tighten Less" in the next period and if B does not, Country A will play "Tighten More" in every future period, and Country B may do the same. The assumption by each country that the other is following such a "trigger strategy" may be enough to ensure that A will always play "Tighten Less" and vice versa. ${ }^{8}$

The reason why trigger strategies can support repeated play of efficient policies is that for each country the value of deviating from the efficient policy in each period is outweighed by the discounted value of having efficient policies played in the future. Therefore, for trigger strategies to work, there must be at least some probability each period that the game will continue, and outcomes in the future must not be discounted "too heavily".

Even if this condition is met, the "Folk Theorem" tells us that there are many possible Nash equilibria in repeated games including both repeated play of efficient policies (like Tighten Less) and repeated play of the noncooperative policies (like Tighten More). Therefore, one function of international policy coordination fora might be to coordinate on the Nash equilibrium of the repeated game that involves repeated play of efficient policies.

\section{II.F Contact in Several Areas}

It has been pointed out that countries interact on other important kinds of policies besides macroeconomic policy, such as trade and defense policy. ${ }^{9}$ The gains from coordinating several kinds of policies may be significant even if the gains from

\footnotetext{
${ }^{8}$ Repeated interaction with incomplete information, a finite horizon, and no coordination can lead to outcomes similar to those under repeated interaction with complete information, an infinite horizon, and coordination on efficient policies. Countries may not know each other's "types", that is, each other's preferences. Repeated interaction makes it possible for countries to build "reputations" for being of a certain type. A country may have an incentive to play the efficient policy for much of the finite horizon even if it intends eventually to deviate from that policy, because it can gain more from deviating if it first builds up a reputation for choosing the efficient policy. [Canzoneri and Henderson (1991)].

${ }^{9}$ Putnam and Henning (1989) discuss the implications of the fact that countries interact on several kinds of policies. Basevi, Delbono, and Delnicolo (1990) consider interactions on both trade policy and macroeconomic policy.
} 
coordinating any one kind of policy are not. Also the opportunities for coordinating the different kinds of policies are staggered, so countries can verify what has happened to one kind of policy before deciding what to do in another. It would be useful to have more analysis of the implications of interactions on several kinds of policies.

\section{II.G Model Uncertainty}

There is also uncertainty over what the model of the economy is; what its parameters are; what its structure is and the type of shocks it faces. Not only do nations not necessarily know the "true" model of the economy, they also do not necessarily know the model that other countries believe to be true. While Frankel and Rockett (1988) first pointed out that nations might lose by working together under uncertainty ex-post, Ghosh and Masson $(1991,1994)$ show that uncertainty is likely to increase the potential gains ex-ante. First, countries may have different information sets that they can share, and by doing so get better expected outcomes. In models where policy makers must set their policies before uncertainty is resolved, the expected gain from coordination is greater whenever there is multiplicative or parameter uncertainty. Ghosh and Masson further argue that uncertainty provides a rationale for episodic efforts at coordination, since crises generate large uncertainties, and hence potential gains, and are also, fortunately, infrequent.

\section{II.I "Counterproductive Coordination"}

Several analysts have put forward examples in which what they define as coordination is counterproductive. ${ }^{10}$ As stated above, in the terminology of the policy coordination literature, cooperation is only possible when commitment is possible. In the examples designed to show that coordination can be counterproductive, it is assumed that the participants in the policy game cannot credibly make all of the commitments necessary for achieving the efficient equilibrium but that some participants can commit to jointly maximize and play Nash against others. This type of commitment is called "coordination", and this type of coordination can be counterproductive for those who engage in it.

In the example of Rogoff (1985a), the authorities in each of two countries have an "inflation bias" problem because desired outputs are above natural outputs. Even though inflation is costly, the equilibrium rate of inflation must be high enough that the incentive to increase the money supply in order to raise output is just offset by the extra cost of additional consumer price index (CPI) inflation. In a two-country world with noncooperative behavior, an increase in the money supply in one country increases its inflation both by increasing its output price inflation and by causing its currency to

\footnotetext{
${ }^{10}$ Rogoff (1985a) and Oudiz and Sachs (1985) produced the earliest examples, and Canzoneri and Henderson (1991) produced another. Tabellini (1990) produced an important example involving two political parties in each of two countries.
} 
depreciate in real terms, making imports more expensive. ${ }^{11}$ With joint maximization between monetary authorities and noncooperative play against the private sector, when one country expands its money supply the additional real depreciation of its currency helps the other country by lowering CPI inflation there. Therefore, the extra cost of CPI inflation for the two countries taken together is lower and the equilibrium rate of inflation must be higher if the incentive to try to raise output is to be matched by additional joint costs of CPI inflation. Thus, the inflation bias in both countries is higher.

Existing examples of counterproductive coordination leave a key question unanswered. The commitment of some of the participants to jointly maximize and play Nash against other participants must be taken seriously and acted on by the other participants. If this kind of commitment is credible, why is it not credible to commit to deliver an efficient outcome? Both kinds of commitment require those making the commitment to be off their Nash reaction functions. Since existing examples provide no answer to the key question, in our view they are not convincing. Indeed, we regard them as examples of the kind of outcomes that would never occur. The agents who can make credible commitments have an incentive to avoid commitments that lead to these outcomes and to make other kinds of commitments which can improve outcomes or at least not worsen them, and the other agents have every reason to take these other commitments seriously.

\section{II.J Monetary Policy and Fiscal Policy}

The analysis of stabilization policy often proceeds under the assumption that monetary policy is the only policy instrument. ${ }^{12}$ There are several explanations for why this assumption is made. First, the general criticism of stabilization policy in the 1970s and thereafter fell most heavily on fiscal policy, at least in part because fiscal policy had played a major role as a stabilization instrument in the 1950s and 1960s. Second, monetary policy is more flexible and it became conventional wisdom that fiscal policy is too inflexible to be useful as a stabilization tool. Third, the analysis of stabilization conflicts among countries is much simpler when it is assumed that there is only one instrument in each country and, given other considerations just mentioned, it is was natural to choose monetary policy as that instrument.

In a closed economy, if the only two targets of policy are the output gap and CPI inflation, then there is a need for either monetary policy or fiscal policy as a stabilization

\footnotetext{
${ }^{11}$ The first order conditions for a monetary authority with noncooperative behavior and joint maximization are given in Appendix A.

${ }^{12}$ From, for example, the survey of Persson and Tabellini (1995), it is evident that for the most part monetary policy and fiscal policy have been studied separately in the policy coordination literature. As stated in the text, in analyses of stabilization conflicts it is usually assumed that monetary policies are the only instruments. In the complementary analyses of ongoing conflicts over spending priorities and tax collections at full employment, it is usually assumed that fiscal policies are the only policy instruments.
} 
instrument, but not both. ${ }^{13}$ In the short run, the output gap and the inflation rate are linked by the aggregate supply curve or Phillips curve. Therefore, choosing the output gap is the same thing as choosing the inflation rate. Both monetary policy and fiscal policy affect only the aggregate demand schedule. If shocks are known before policy is set, shocks to the aggregate demand curve (money demand shocks or goods demand shocks) can be exactly offset by either monetary or fiscal policy. Shocks to aggregate supply cannot be exactly offset but the best attainable output-gap/inflation pair can be achieved by either monetary or fiscal policy through shifts in the aggregate demand schedule. In order to make the problem of choosing the optimal mix of monetary policy and fiscal policy meaningful, it is necessary to add another target for policy such as a desired level of government spending based on public finance considerations or a desired level of investment (or, as a proxy, the real interest rate) based on long-run growth considerations.

In a two-country world economy, if the only two targets of policy are the output gap and CPI inflation, the situation is somewhat more complicated. First suppose that the only shocks are money demand and goods demand shocks in each of the two countries. If both monetary policy and fiscal policy are available in both of the two countries, then bliss is attainable and, in general, all four policies are needed. ${ }^{14}$ In each country, monetary policy offsets the money demand shock and fiscal policy offsets the goods demand shock. Now suppose that the only shocks are productivity shocks. If both monetary and fiscal policy are available in both countries, there is no Nash equilibrium. In each country, CPI inflation depends only on the output gap and the real exchange rate (the price of one country's goods in terms of the other's). Thus, each country can use one instrument to keep the output gap at zero and use the other to attempt to move the real exchange rate to the value that it prefers. The values of the real exchange rate desired by the two countries will be different, so each country finds it in its interest to move its instruments without limit in an attempt to achieve its desired real exchange rate while always keeping its output gap at zero.

It is clear that the output gap and CPI inflation are not the only targets of macroeconomic policy. As indicated above in the discussion of a closed economy, countries may have targets for the government spending or investment. In addition, countries may have targets for actual or structural government deficits, ratios of government debt to gross domestic product (GDP), or current account balances. For example, the Maastricht Treaty establishes norms for actual deficits and debt ratios for the members of EMU. In general, when countries have target variables other than the output gap and CPI inflation, no matter what the source of shocks, bliss is not attainable so there are stabilization policy conflicts, and a Nash noncooperative equilibrium exists.

\footnotetext{
${ }^{13}$ The output gap and the employment gap can be used interchangeably. If it is assumed that supply of labor is perfectly inelastic, then variation in the employment gap is the same as variation in employment.

${ }^{14}$ This result and the other result stated in this paragraph are proved in Appendix A.
} 
There are several notable exceptions to the general practice of ignoring fiscal policy in analyses of international stabilization conflicts. In all of the contributions that allow for both monetary and fiscal policy, countries have targets in addition to the output gap and inflation. However, there is as yet not complete agreement about what the additional targets of macroeconomic policy should be. A non-exhaustive list of candidate variables includes the current account, government spending, domestic goods consumption, imported goods consumption, the total taxation rate, the non-indexed government debt-GDP ratio, the government deficit GDP ratio, the pubic sector borrowing requirement, the short-term interest rate, the direct taxation rate, and autonomous taxation. ${ }^{15}$ To make progress in analyzing the international coordination of monetary and fiscal policy, it will be necessary to devote more effort to deciding on exactly what the targets of macroeconomic policy should be.

When countries have more than two target variables, models become considerably more complex. Frequently, it is either not informative to rely on analytical results or not even possible obtain such results, so simulation results are reported instead. The one very important but not very surprising conclusion that emerges from these studies is that to achieve the best results, both monetary and fiscal policy must be coordinated among countries. To make progress in analyzing international macroeconomic policy coordination it will be necessary to rely heavily on estimated or calibrated economic models. As yet it is not clear whether the appropriate analysis will yield a few very general precepts or results that depend heavily on the particular shocks and model under consideration.

\section{II.K Information Exchange}

As is well known, one of the major activities at actual meetings on policy coordination is the exchange of information. As is also well known, in much of the early theoretical work on policy coordination there is no need for the exchange of information. It is assumed that all the agents have all relevant information, as in the simple example at the beginning of this paper.

In some of the later theoretical work, there is scope for the exchange of information. As pointed out above, in infinitely repeated games when trigger strategies

${ }^{15}$ In the seminal paper of Oudiz and Sachs (1984), the target variables include the current account. In Eichengreen and Ghironi (1999), Levine and Pearlman (1997) and (1998), and Alesina and Tabellini (1987), the target variables include government spending. In each of two works by McKibbin and Sachs (1988 and 1991) and in each of the four papers in the volume edited by Currie and Levine (1993) (Krichel, Levine, and Pearlman; Christodoulakis, Gaines, and Levine; Levine and Currie; and Currie and Levine), the target variables include a subset of domestic goods consumption, imported goods consumption, government spending, the total taxation rate, the non-indexed government debt-GDP ratio, the deficit-GDP ratio, the pubic sector borrowing requirement, the current account, the short-term interest rate, the direct taxation rate, and autonomous taxation. 
are considered, there are multiple equilibria which include both the efficient equilibrium and many inefficient equilibria. Thus, there is scope for the countries to communicate about which of the possible equilibria are better and what strategies they intend to follow. When one country says it will follow some strategy which is in its own best interest given that the other country follows some other strategy, the first country has every incentive to follow through on what it says if the second country does also. In game theory, exchange of such information is referred to as "cheap talk." coordination on the efficient equilibrium.

Ghosh and Masson (1994) provide examples in which exchanging information may lead to either better or worse outcomes when countries act noncooperatively. Their findings are another example of the general principle that when there are two distortions removing one distortion may not improve the outcome. For example, in a noncooperative setting with externalities like our canonical example and with lack of full information, exchanging information does not necessarily lead to a better outcome because the Nash equilibrium is still inefficient. Of course, when nations coordinate policies, exchanging information always improves outcomes.

Recently there have been advances in the analysis of information exchange in the game theory literature. It would be useful to investigate the extent to which these advances can be applied to the analysis of policy coordination.

\section{II.L Quantitative Analysis}

There is an extensive literature on the quantitative analysis of policy coordination. A comprehensive survey of that literature is beyond the scope of this paper. ${ }^{17}$ Instead we summarize what we take to be the conventional wisdom regarding the gains from achieving cooperative (efficient) outcomes instead of conventional noncooperative outcomes. ${ }^{18}$ This conventional wisdom is consistent with the conclusions of many but not all studies. ${ }^{19}$ We also discuss extensions of the quantitative analysis in which both the approach and the conclusions are somewhat different.

\footnotetext{
${ }^{16}$ For a discussion of the application of the "cheap talk" concept in economic models see Farrell and Rabin (1996) who define cheap talk as "costless, nonbinding, nonverifiable, messages that may affect the listener's beliefs."

${ }^{17}$ McKibbin (1997) provides such a survey.

${ }^{18}$ Efficient outcomes can always be achieved by cooperation. However, they can sometimes be achieved without cooperation, for example by using trigger strategies. For simplicity, in this section we refer to efficient outcomes as cooperative outcomes as is conventional in the quantitative coordination literature.

${ }^{19}$ There is a closely related literature on the comparison of alternative policy regimes. A regime is a specification of simple policy rules for two or more countries, usually the same rule. Using quantitative models, countries are subjected to several types of shocks under alternative regimes. The objective is to determine which regime performs best for
} 
Oudiz and Sachs (1984) (OS) are the first to estimate the gains from cooperation. They use the reduced forms of two econometric models and (quadratic) country welfare functions. In these welfare functions the target variables are the output gap, inflation, and the current account surplus; and the relative weights were inferred from a baseline forecast for the years 1984-1986. OS find gains of between one-half and one percent of GDP per year for each of the country blocs considered.

Over the ensuing eighteen years there have been many other estimates of the welfare gains between cooperative and conventional noncooperative outcomes. Each set of estimates is based on a quantitative model and country welfare functions. In some cases, the parameters of the quantitative model are determined by estimation, and in others they are determined by calibration. Sometimes the country welfare functions include different variables from those used by OS. Often the weights for the target variables are chosen by the analyst rather than inferred from a baseline forecast.

What is remarkable is that despite some differences among the methods used to obtain them, many of the estimates of the welfare gains from cooperation have been close to the OS estimates. However, there are some notable exceptions with considerably higher estimates, from an average of 2.8 to an average of 7.4 times as high as the OS estimates. ${ }^{20}$ Despite these exceptions, the conventional wisdom is that the gains from cooperation are roughly between one-half and one percent of GDP per year, as confirmed by McKibbin (1997).

Whether the welfare gains from cooperation found by OS and the many studies that followed are large or small is to a large extent in the eye of the beholder. Gains of one-half to one percent a year are of the same order magnitude as estimated gains from the Uruguay Round of trade agreements. In any case, most analysts regard the gains

which types of shocks and whether any regime seems to be preferable for most kinds of shocks. McKibbin (1997) also provides a thorough survey of this literature.

${ }^{20}$ Hughes Hallet (1986) finds gains from cooperation of .47 and 1.35 percentage points of annual GDP growth for five years for the United States and Europe, respectively. Translated into level terms to make them comparable with OS, these gains are 1.4 and 4.1 percent of GDP per year on average. Becker, et al. (1986) find gains ranging from 1.8 to 3.3 percentage points of unemployment per year for five years for the United States and five European countries. Translated into terms of GDP using an Okun's law coefficient of 3, these gains range from 5.4 to 9.9 percent of GDP per year. 
from cooperation as small. ${ }^{21}$ When the gains arise from cooperative responses to shocks, they are usually deemed to be small relative to the size of the shocks. ${ }^{22}$

A handful of authors have extended the quantitative analysis of policy coordination to include outcomes other than the cooperation and conventional noncooperative outcomes. They have considered three types of gains: Type I gains are realized by moving to the cooperative outcome from the conventional noncooperative outcome, Type II gains are realized by moving to the conventional noncooperative outcome from a constrained noncooperative outcome, and Type III gains are realized by moving to a constrained noncooperative outcome from the historical outcome. Type I gains are measured by OS and most other investigators. Type II and Type III gains are measured in the extensions. The main conclusion of the extensions is that the sum of Type II and Type III gains are often an order of magnitude larger than Type I gains, because at least one component of the sum is an order of magnitude larger. ${ }^{23}$ In other words, taking the final step from the conventional noncooperative outcome to cooperation is less important than taking one or the other of the earlier steps.

The justification for considering Type II and Type III gains is that countries can attain the conventional noncooperative outcome only under quite strong assumptions. Each country must have the same considerable amount of information about the structure of the world economy, any shocks, and the tastes and actions of all countries. In addition each country must use this information in a relatively sophisticated way: using its own welfare function, it must calculate its optimal policy response for any given policy responses by all the other countries. It is argued that these assumptions may often not be met and that countries may have to communicate more or become more sophisticated in their use of information if they are to realize Type II and Type III gains.

The challenge in considering Type II and Type III gains is to construct plausible alternatives to the conventional noncooperative outcome. History is a clear alternative as long as it can be argued convincingly that history should not be regarded as conventional noncooperative outcome. ${ }^{24}$ It is certainly true that historical outcomes are sometimes

${ }^{21}$ Similarly, according to Feenstra (1992), the estimated gains from trade agreements, which are on the order of one percent or less of GDP per year, are regarded as small by most trade economists.

${ }^{22}$ Obstfeld and Rogoff (2001) have reinforced the conventional wisdom that the gains from cooperation are small. The authors use a model that exemplifies the 'new open economy macroeconomics.' Recently, several other authors have used similar models to analyze policy coordination. It is beyond the scope of this paper to survey these recent contributions.

${ }^{23}$ See the next three footnotes.

${ }^{24}$ Hughes Hallet (1986) finds that for the U.S. and Europe Type III gains are roughly 9.5 and 8 times as large as Type I gains, respectively. See also footnote 20. 
quite different from those implied by the plausible welfare functions and the mainstream quantitative models used by investigators. Other alternatives are generated by relaxing one or another of the strong assumptions that underlie the conventional noncooperative outcome. One such alternative is a 'limited information' noncooperative outcome. ${ }^{25}$ This kind of outcome arises when countries do not combine their information to make, for example, the best possible estimates of current shocks. Another such alternative is an 'insular' or 'isolationist' noncooperative outcome. ${ }^{26}$ This kind of outcome arises when there is a shock and each country maximizes its own welfare assuming (counterfactually) that the others will stick to their pre-shock policies rather than make the optimal response to the shock.

Two other pairs of authors have extended the quantitative analysis of policy coordination in yet other ways. In a book, one pair or provides a thorough analysis of the implications of model uncertainty for the gains from cooperation. They find that with model certainty the gains from cooperation are considerably larger than those found by OS and that with model uncertainty the gains are increased substantially. ${ }^{27}$ The other pair finds that although industrialized country cooperation generates relatively small gains for these countries, it may generate 'substantial' gains for the developing world. ${ }^{28}$ For example a cooperative disinflation by the industrialized countries yields a significantly lower world interest rate than a noncooperative disinflation, thereby raising the welfare of the developing world.

${ }^{25}$ In their 'U.S. Deficit Game,' Canzoneri and Edison (1990) compare a 'coordinated' noncooperative outcome based on correct information about the U.S. deficit with an 'uncoodinated' noncooperative equilibrium based on an estimate of the U.S. deficit constructed by putting equal weights on the correct information and a plausible alternative. Moving from the uncoordinated outcome to the coordinated outcome reduces loss from 25 to 31 percent of the uncoordinated loss for one quantitative model and from 6 to 20 percent for another. In contrast, moving from the coordinated noncooperative outcome to cooperation reduces loss by less than one percent of the coordinated noncooperative loss.

${ }^{26}$ Hughes Hallet (1986) finds that for the U.S. and Europe Type II gains are roughly 29 and 2 times as large as Type I gains, respectively. See also footnote 20. In their U.S. and Europe disinflation example, Canzoneri and Minford (1989) find that for the U.S. and Europe Type II gains are roughly 2 and 7 times as large as Type I gains, respectively.

${ }^{27}$ According to Ghosh and Masson (1994), with model certainty and with model uncertainty, respectively, the gains from cooperation average 6 percent and 10 percent of GDP per year forever.

${ }^{28}$ Sachs and McKibbin (1985) estimate gains for the developing countries that they characterize as substantial. Unfortunately, they do not present their estimates in a way that makes it easy to evaluate their characterization. 
According to conventional wisdom, the gains from cooperation are small. However, several investigators have found significant gains from cooperation or coordination on better noncooperative outcomes. It appears that the case is not closed and that, therefore, there is scope for further quantitative analysis of policy coordination.

\section{II.M Papers Produced Earlier in Connection with the GEI Project}

In preparing for this conference we have had a chance to familiarize ourselves with five papers produced earlier in connection with the Global Economic Institutions (GEI) Project. Two of the papers are empirical. Bai and Hall (1996) use a common factor approach to try to test for the degree of symmetry in the shocks to output, employment and interest rates in Europe, the United States and Japan. They find that there is some evidence of common shocks to the United States and the EU, with little common persistence but similar common volatility. They also find that there is little to no relationship between the shocks in the US and Japan. This work is particularly interesting since countries should react and cooperate differently depending on the degree of symmetry of shocks. Caporale et al. (1998a and 1998b) look at the gains to coordination among the G-3 where the "shock" is a unilateral monetary or fiscal tightening in the United States. They report gains to coordination which are similar to those in the literature within a three-year horizon.

The remaining three papers are theoretical and show that delegation of the type proposed by Rogoff (1985b) can be counterproductive for policy coordination. ${ }^{29}$ Rogoff shows that a closed economy with a social welfare function that implies inflation bias can reduce that bias by delegating monetary policy to a "conservative" central banker, one whose personal welfare function has a higher weight on an inflation objective than the social welfare function. However, the conservative central banker does not respond optimally to productivity shocks because he lets the output gap vary more than would be desirable and lets inflation vary too little. Thus, there is a trade off between the average level of inflation and stabilization performance.

Among the GEI papers, Currie, Levine and Pearlman (1996a, 1996b) argue that if each of two countries delegates monetary policy to Rogoff-type conservative central bankers, stabilization performance may be compromised, and if shocks are symmetric, international policy coordination may be counterproductive ${ }^{30}$. These findings seem to follow naturally from Rogoff's finding for a closed economy. In the context of our above game (i.e. in the face of a symmetric productivity shock) coordinated monetary policy

\footnotetext{
${ }^{29}$ In an another paper, Rogoff (1985a) showed that what he called coordination could be counterproductive.

${ }^{30}$ The primary focus of these papers is that delegating to a conservative central banker and then playing non-cooperatively can be worse than not delegating, for the same reasons as in the cooperation case. They also show that if the nations cooperate when choosing the type of central banker before then playing non-cooperatively, the countries will choose 'anti-conservative' central bankers when the shocks are symmetric.
} 
leads to less tightening than noncooperative monetary policy. Conservative central bankers coordinating and, therefore, acting like a single authority contract less than they would if they acted noncooperatively, but they still contract more than would be implied by the social welfare function. Levine and Pearlman (1997) expand on Currie et al. (1996b) by taking account of fiscal authorities both countries. When fiscal policy has an additional externality, delegating to conservative central bankers may be even more counterproductive. The paper further demonstrates that commitment to joint maximization among a subset of agents who then play noncooperatively against the rest may not be welfare enhancing.

To provide some perspective on the GEI papers it is important to consider the findings of Walsh (1995). He shows that under the usual assumptions, there is a contract for the head of the central bank that completely eliminates inflation bias without compromising stabilization performance. Thus, with Walsh-type contracts, there is no trade-off between the average inflation rate and stabilization performance. Walsh-type contracts involve linking the compensation of the head of the central to inflation performance. There is much disagreement about whether it is feasible to implement Walsh-type contracts and, therefore, about whether there is a trade off between the average inflation rate and stabilization performance. Coordination among policy authorities subject to Walsh-type contracts is not counterproductive.

\section{Experience of Policy Coordination since $1973^{31}$}

This section is a selective review of the experience with policy coordination since the breakdown of the Bretton Woods System. It focuses on two areas in which policy coordination has received the most public attention, namely the global G-7 process which includes the largest industrialized countries, and the European process of Economic and Monetary Union (EMU). ${ }^{32}$

III.A. The Group of Seven

III.A.1 Evolution of the G-7

\footnotetext{
${ }^{31}$ This section and Appendix B are based largely on historical accounts contained in Ainley (1984), Bryant (1995), Dobson (1991), James (1996), Kenen (1996), Putnam and Henning (1989), Solomon (1982), and Solomon (1999), as well as the texts of G-7 and Ecofin statements.

${ }^{32}$ Other fora for macro policy discussions among the major economies include the Economic Policy Committee (EPC) and its Working Party 3 (WP-3) of the Organization for European Cooperation and Development (OECD), the Executive Board and International Monetary and Financial Committee of the International Monetary Fund (IMF), and the G-10 central bank governors meetings and other meetings at the Bank for International Settlements (BIS).
} 
The G-7 traces its roots to ad hoc, and often secretive, meetings of the Group of Five finance ministers and central bank governors. ${ }^{33}$ In March 1973, U.S. Treasury Secretary George Shultz invited the German, French, and British Finance Ministers (Helmut Schmidt, Valery Giscard d'Estaing, and Anthony Barber) to an informal meeting in the ground floor library of the White House. At the first meeting of what was initially called the "Library Group," participants agreed to abandon attempts to reestablish fixed parities between the dollar and European currencies, thereby helping to usher in the floating rate era. The Japanese Finance Minister was invited to join the group in the fall and central bank governors were invited soon afterward, thus establishing the G-5 process.

The process gained added momentum with the launching of annual economic summits. Soon after they became Heads of their respective governments, original Library Group members Schmidt and Giscard invited the Leaders of the other G-5 countries plus Italy to Rambouillet, France in November 1975. Canada attended the 1976 summit in Puerto Rico to complete the Group of Seven at the Head of State/Government level. Despite the participation of seven countries at the Leaders' summits ever since 1976, the ministerial process remained largely limited to the G-5 during the 1970s and early 1980s.

The G-5 finance ministers and central bank governors released their first official statement in January 1985 and they attracted worldwide attention with the Plaza Agreement of September 1985. Shortly afterwards, the group expanded to become the G-7 with the addition of Italy and Canada in $1986 .{ }^{34}$ The G-7 finance ministers and central bank governors have met regularly every year since 1986, always immediately before the IMF/World Bank spring and fall meetings, and often in January or February.

Deputy finance ministers have participated in the process since the beginning, while there was no equivalent on the central bank side at first. Over time the finance deputies have taken on a greater role in steering the process. Central bank deputies have long been invited to participate in biannual surveillance discussions with their finance deputy colleagues. In recent years, central bank deputy governors have begun to meet or call each other regularly to coordinate central bank participation in the G-7 process more broadly.

At the Leaders' summits, the President of the European Commission has attended regularly since 1977 and he has been joined by the President of the European Council since 1986. The President of Russia was invited to meet with the G-7 Leaders at the end

\footnotetext{
${ }^{33}$ The G-5 countries are the United States, Japan, Germany, France, and the United Kingdom. The G-7 adds Italy and Canada.

${ }^{34}$ For some time after the creation of the G-7 ministerial process, the G-5 ministers and governors continued to meet occasionally. Indeed, Italy boycotted the famous Louvre accord of 1987 because it was discussed within the G-5 first before it was to be discussed by the G-7.
} 
of their 1991 summit and Russia's participation has increased over time such that the summit is now called the G-8 Summit. However, during the summit, the leaders of the original seven arrange some time to meet without Russia to discuss macroeconomic policies and certain other IMF-centered issues, such as debt relief.

The summit process is guided by "sherpas" representing the leaders of each country and "sous-sherpas" from the Finance and Foreign ministries of the participating countries plus the European Commission. Despite much overlap between sous-sherpas and G-7 deputy finance ministers, the G-7 finance ministry and central bank process still does not include European Commission or Russian participation on a regular basis. With the launch of the euro in 1999, the President of the ECB and the Chair of the Euro-11 Council have assumed a limited role in the G-7 process while the group considers the issue of euro-area representation in the long term.

\section{III.A.2 Macro Policy Coordination in the G-7}

The new G-5's first attempt at policy coordination occurred in the wake of the oil price shock of December 1973. As each country began to experience higher inflation and a deteriorating balance of payments, the world faced the danger of excessive monetary and fiscal contraction as each country's tighter policies tended to raise inflation and reduce net exports in its neighbors. This is one of the classic examples in the literature for gains from international coordination by taking account of externalities. Rather than agree on specific macro policies, however, the G-5 decided to push a new oil adjustment facility in the IMF to give countries an alternative to fiscal tightening. ${ }^{35}$ In addition, the G-5 agreed to establish the International Energy Agency, affiliated with the OECD, as a forum for oil importing nations to discuss energy strategies.

The next attempt at macro policy coordination took place at the London summit of 1977, when Leaders agreed on unspecified, but widely acknowledged, growth targets. Failure to achieve the London growth targets led to specific policy pledges at Bonn in 1978 that appeared to be a classic example of cooperative game playing. The United States pledged to decontrol domestic oil prices, while France, Germany, and Japan pledged specific fiscal expansions. A formula to conclude the Tokyo Round of trade negotiations was also part of the bargain. It is important to recognize that there was a pre-existing domestic faction in each country pushing for these policies, especially the fiscal expansions. For the United States on oil and France on trade, the summit agreement may have helped tip the balance of domestic forces, but it could never have succeeded without the domestic pressure groups. In Germany and Japan, politics were

\footnotetext{
${ }^{35}$ In its first two years of operation, the oil adjustment facility lent a total of $\$ 8.3$ billion to 55 countries. After 1977, the oil adjustment facility was wound down, but the principle of lending more flexibly in the face of oil and other commodity price shocks was incorporated into other IMF facilities.
} 
already strongly heading toward fiscal expansion even before the summit. All of the participants essentially carried through with the agreements reached in Bonn. ${ }^{36}$

Many commentators have viewed the burst of global inflation and subsequent recession in 1979-81 as evidence that the Bonn summit was a failure because it promoted misguided policies. In particular, it has been argued that by the time coordinated policies were agreed upon the economic problems had already shifted. However, it is also true that the Iranian revolution and Organization of the Petroleum Exporting Countries (OPEC) oil shock of 1979 could not reasonably have been predicted in 1978, so that the poor outcomes of 1979-81 were only partly due to mis-timed policies adopted in Bonn.

The elections of Margaret Thatcher and Ronald Reagan led to a cessation of serious attempts at policy coordination in the early 1980s, as these leaders tended to favor unilateral action and were generally suspicious of international coordination in all spheres. By 1985, however, the relentless rise of the dollar and the burgeoning U.S. current account deficit led to a change of heart.

The Plaza Agreement of September 1985 and the Louvre Accord of February 1987 marked the high-water points of policy coordination in the post-Bretton Woods era. Each of the G-5 (later G-7) countries promised to undertake a list of specified policy actions and to cooperate in currency intervention. (Currency intervention will be discussed in the next section.) Formal statements by the G-7 during this period indicated that there was broad satisfaction with growth and inflation performance in the major economies. The primary area of concern was the large external imbalances between the major regions, which were raising protectionist pressures that the Leaders feared they could not resist.

Under Plaza, specific commitments include:

- $\quad$ The United States promised to reduce its fiscal deficit by more than 1 percent of GDP in FY 1986 and to continue further reductions in the future.

- Japan promised to liberalize its financial markets to ease consumer credit, to facilitate the internationalization and strengthening of the yen, and to conduct monetary policy "with due attention to the yen rate."

- Germany promised tax cuts and a progressive reduction of the share of the public sector in the economy.

- $\quad$ All countries promised to resist protectionist pressures and to pursue unspecified structural reforms in a variety of sectors to increase economic efficiency.

Under Louvre, specific commitments include:

\footnotetext{
${ }^{36}$ For a careful treatment of the Bonn summit and its outcomes, see Putnam and Henning (1989).
} 
- $\quad$ The United States promised to reduce its fiscal deficit from 3.9 percent of GDP in FY1987 to 2.3 percent in FY1988.

- Japan promised to cut its discount rate by 0.5 percent.

- $\quad$ France promised to cut taxes by 1 percent of GDP while lowering the fiscal deficit by the same amount between 1986 and 1988 .

Many of the promises not listed above were so vaguely worded that it is pointless to discuss whether they were implemented. In the more specific monetary and fiscal areas, the monetary commitments were fulfilled, at least for a short while. The fiscal commitments largely were not achieved, particularly French promises to reduce taxes, Japanese promises on fiscal stimulus, and U.S. pledges on deficit reduction. ${ }^{37}$

Many Japanese observers regard the Louvre Accord as the beginning of Japan's bubble economy because it contained a brief reference to Bank of Japan (BOJ) plans to lower the discount rate by 50 basis points and because Treasury Secretary Baker spoke out against looming interest rate increases in Germany and Japan later that year. In fact, pressure on Japan to ease monetary policy started much earlier and was already evident in the language of the Plaza Agreement. ${ }^{38}$ However there was no pressure evident in public statements from U.S. officials or in G-7 communiqués to ease Japanese monetary policy during the 1988-90 period when the bubble was most pronounced.

Beginning at the end of the 1980s and continuing to the present day, G-7 statements have avoided specific macro policy obligations in favor of a general sense of the desired direction of individual policies in the different regions. At the same time, more effort has been placed on ensuring that participants have a common understanding of the problems to be addressed. The macroeconomic surveillance process was formalized to cover specific indicators of growth, inflation, monetary and fiscal conditions, and external imbalances on a regular basis. The role of the IMF was enhanced in the late 1980s to support this surveillance process, including through the preparation of surveillance papers for discussion. The purpose of these changes was to monitor consistency in policies across countries and to encourage participants to consider the medium-term implications of policy stances.

The large current account imbalances of Japan and the United States have continued to be a major focus of discussion. The IMF took on the role of impartial observer both in keeping track of the effects of past policies and in assessing the likely

\footnotetext{
${ }^{37}$ Assessing the fulfillment of the fiscal pledges is complicated by the existence of many different revenue and spending programs at all levels of government, by different fiscal years, and because of the unpredictable effect of economic activity on revenues and entitlement spending. This assessment is based on general government revenues and balances tabulated in the OECD Economic Outlook, December 1999, as well as the discussion in Dobson (1991).

${ }^{38}$ Japanese money and credit growth did pick up very slightly in late 1985 and more substantially in late 1987.
} 
impacts of current and proposed future policies. Statements released by the G-7 in the early to mid-1990s tended to focus on the need for the United States and other countries with large fiscal deficits to reduce them. Europe and Japan acknowledged the need for structural reforms to raise employment and private investment. At times, the G-7 also endorsed Japanese announcements of fiscal stimulus plans and encouraged further actions to strengthen the banking system.

The common thrust of these agreed policies was to moderate domestic demand growth in the United States and accelerate domestic demand in Europe and especially Japan. To a large extent, the macroeconomic components of these policies were implemented, particularly the substantial reduction in fiscal deficits in most countries and the substantial increase in Japanese fiscal deficits. Low and stable inflation rates are another area of shared success. However, it is not clear that much credit for these outcomes can be given to the G-7 coordination process, since domestic pressure also existed for these policies. Moreover, continental Europe and Japan clearly did not succeed in stimulating growth through structural reform, the implementation of Japanese fiscal expansion was erratic, and the record of the 1990s shows little success in achieving the goal of reducing external imbalances.

\section{III.A.3 G-7 Currency Intervention}

Perhaps the greatest focus of the public has been on the implications of the G-7 process, and specifically the Plaza and Louvre accords, for exchange rates. The Plaza agreement specifically called for further dollar depreciation. The Louvre accord declared that dollar depreciation had gone far enough. Both announcements described participants as being ready to cooperate closely to encourage the desired exchange rate adjustment whenever it was appropriate. In this context, "cooperate" is generally accepted as code for concerted intervention. Over time, language affirming "close cooperation in the exchange markets where appropriate" has been a frequent, but not universal, element of G-7 statements.

The motivation for currency intervention is to avoid large swings in exchange rates that bring about unsustainable current account imbalances and impose large adjustment costs on the economy. To the extent that these swings are induced by the fundamental macroeconomic policy mix, currency intervention is ineffective at best and harmful at worst. However, when financial markets overshoot the exchange rates consistent with fundamental policies, intervention may be able to help restore equilibrium, although such a presumption is not universally accepted.

While they have not publically committed to specific currency interventions in advance, G-7 participants have engaged in concerted intervention on occasion ever since the original G-5 in the 1970s. ${ }^{39}$ In 1985, intervention associated with the Plaza

\footnotetext{
${ }^{39}$ The Jurgensen Report - published in 1983, but whose conclusions had already been accepted by much of the economics profession - cast doubt on the effectiveness of sterilized exchange rate intervention and may have been partly responsible for the lull in intervention activity in the early 1980s.
} 
agreement aimed at hastening the dollar's depreciation. In 1987, intervention aimed at preventing further depreciation. In 1989, intervention sought to limit the dollar's appreciation. From the U.S. perspective, intervention peaked in 1989, when U.S. authorities sold over $\$ 22$ billion to purchase DM and yen, largely in concert with Germany and Japan.

Coordinated intervention declined markedly in 1990 and 1991, and U.S. and German authorities virtually ceased intervention in 1992 and 1993. Coordinated intervention picked up modestly in 1994 and 1995 in an attempt to restrain the rise of the yen, and to a lesser extent, the DM. After the dollar's rebound in late 1995, U.S. authorities ceased intervention entirely in 1996 and 1997. The only instance of coordinated intervention since 1995 occurred in 1998, when the United States joined Japan on one day in June to halt the sharp depreciation of the yen.

Despite the virtual abandonment of coordinated intervention in recent years, Japanese authorities have continued to intervene frequently on a unilateral basis.

Moreover, G-7 statements regularly repeat the threat of possible future coordinated intervention if warranted by the circumstances. At the September 1999 G-7 meeting, participants hinted that coordinated intervention to deflect the yen's appreciation might be forthcoming in conjunction with further steps to ease monetary conditions by the Bank of Japan. While the language of the January 2000 statement on exchange rates was little changed from September, participants seemed less inclined to consider coordinated intervention, as the BOJ judged that prospects for recovery lessened the need to consider easing monetary policy further. Many Japanese officials do not want to repeat the perceived mistake of bowing to international pressure for loose monetary policy, such as has been attributed to the Louvre Accord.

\section{III.A.4 Other Policies in the G-7}

Over time the G-7 has expanded its interests beyond macroeconomic surveillance and exchange markets to include the full range of IMF policies and other international economic issues such as the transition of former socialist economies, debt reduction for poor and heavily indebted countries, environmental issues, corruption and money laundering, and reform of the international financial system. Concrete outcomes of this process include increased IMF lending to Russia, adoption of the OECD anti-bribery convention, the HIPC initiative, and the new Financial Stability Forum. The G-7 is also the core of the new G-20 mechanism for dialogue with key emerging markets on global financial and economic developments and institutions.

In addition, the network of contacts built up by the G-7 process proved invaluable in addressing fast-breaking crises such as the need to secure funding for the Gulf War effort in 1990-91, the rescue package for Mexico in 1994-95, and similar packages for Thailand, Korea, and Indonesia in 1997-98.

\section{III.B European Economic and Monetary Union}




\section{III.B.1 Evolution of Coordination in the Euro Area}

In December 1969, the European Council appointed Pierre Werner of Luxembourg to draft a report on the feasibility of economic and monetary union. The Werner Report of 1970 outlined the path to monetary union. In 1971, the finance ministers of the European Community endorsed the goal of economic and monetary union by 1980 .

The first concrete step down this path was the creation of the European currency "snake," which was limited to a small core of countries that pledged to keep their currencies within 2-1/4 percent of each other. The snake was launched in March 1972. Original members were the six European Community countries (Germany, France, Italy, the Netherlands, Belgium, and Luxembourg) plus Denmark. The United Kingdom joined two months later. Within a year, the United Kingdom and Italy dropped out of the snake. France dropped out in 1974, rejoined in 1975, and dropped out again in 1976.

In 1979 the snake was transformed into the Exchange Rate Mechanism (ERM) at the heart of the new European Monetary System (EMS). France and Italy joined the ERM at its inception, although Italy was given a wide band of \pm 6 percent whereas France and the snake legacy countries had bands of $\pm 2-1 / 4$ percent. In the first three years there were several exchange rate realignments, but over time parity changes become less frequent. Membership in the ERM grew during the following decade, most notably when the United Kingdom joined in 1990.

The aftermath of German unification in 1990 led to policy strains that brought on speculative currency attacks that forced the United Kingdom and Italy out of the ERM by 1992. France persevered, but was forced to accept wider bands in 1993.

The Maastricht Treaty, signed in 1991, succeeded in forcing major fiscal consolidations in all EU countries by the middle to late 1990s. The Stability and Growth Pact of 1996 aimed to cement fiscal gains going forward by establishing goals and incentives for fiscal deficits after monetary union. Italy rejoined the ERM in late 1996 in a bid to qualify for EMU. In May 1998, eleven countries were ratified as initial members of the monetary union based on their fulfillment of the convergence criteria during 1997. Shortly afterward, a subset of the Ecofin, the Euro-11 Council, began to meet to discuss financial and exchange rate policies in the euro area. On July 1, 1998, the European Monetary Institute metamorphosed into the European Central Bank. On January 1, 1999 the euro came into being.

\section{III.B.2 Macro Policy Coordination Experience}

The snake era marked an increase in international macro policy coordination within Europe beyond that achieved through supranational institutions such as the European Commission, the OECD and the IMF and through direct contacts between governments. Finance Ministers and Central Bank Governors of the snake countries and their deputies had to communicate frequently both bilaterally and in meetings on the 
margins of the Economic and Financial Committee (Ecofin, which normally includes only Finance Ministers) and its deputy-level counterpart, the Monetary Committee, which includes both finance ministry and central bank deputies.

The driving force behind increasingly tight monetary links in Europe has been a desire to achieve three objectives: 1) facilitate greater integration of markets by trade; 2) bolster the political integration of Europe via a powerful symbol of unity; and 3) prevent rounds of competitive devaluation that ultimately lead to trade barriers and higher inflation. Whether reducing exchange rate volatility can have a significant impact in achieving the first objective is an empirical question that is open to debate. The role of monetary union in achieving the second objective is outside the scope of economic analysis. However, the role of monetary coordination in achieving the third objective is precisely the focus of much of the theoretical literature on policy coordination.

As discussed in section II of this paper, a common monetary response is optimal in the case of shocks that affect all countries symmetrically. Examples of such symmetric shocks, to a reasonable approximation, are energy price shocks, shocks emanating from U.S. or Japanese macro policies, and developing country financial crises. In addition, when countries agree that they desire to move together to a lower inflation rate, as has been the case for Europe since the mid-1980s, a coordinated monetary policy can yield better outcomes.

A common monetary response generally is not optimal in the case of a shock that affects countries asymmetrically. German unification in 1990 introduced a big, persistent and slow-building asymmetric shock. Loose fiscal policy and high autonomous consumption and investment demand in Germany forced the Bundesbank to increase interest rates much higher than its ERM partners would have preferred. Despite this pressure, Germany's partners refused to accept the Bundesbank's proposal to revalue the Deutschemark. ${ }^{40}$ The result was temporarily slower growth and rising unemployment outside of Germany. While the experience of the United Kingdom after it left the ERM demonstrates the benefits of monetary independence in the face of asymmetric shocks, policy makers in the euro area argue that large asymmetric shocks like German unification are sufficiently rare that the costs associated with them under monetary union are not likely to exceed the benefits from union.

One important aspect of monetary union in Europe is that the European Central Bank (ECB) is the first institutionalized example of symmetric monetary policy cooperation (as opposed to asymmetric pegged exchange rate regimes). In the face of an asymmetric shock like German unification, the ECB will tend to spread the costs around the entire union, whereas under the EMS, the Bundesbank set policy from a German perspective and the other countries faced the unattractive choice of either following suit or risking a loss of monetary credibility by devaluing.

${ }^{40}$ James (1996) p. 485 provides an interesting discussion of the events of September 1992. 
Now that monetary union is a reality in Europe, attention increasingly has focused on coordinating fiscal policies. The Maastricht Treaty placed significant emphasis on limiting the scope for fiscal deficits. This emphasis arose from fears that under monetary union with an expanded common financial market, profligate governments would find it easier to finance large deficits, thereby imposing the externality of higher interest rates on all member countries. The Stability and Growth Pact enshrines a mechanism for punishing such profligate behavior, but it does so by putting obstacles in the way of counter cyclical fiscal policy (at least unless and until countries achieve structural fiscal deficits low enough to "reload the fiscal cannon").

\section{III.C Some Observations on the Historical Experience}

Probably the most striking aspect of the foregoing history is the very different directions taken by policy coordination within Europe as opposed to within the G-7. While the G-7 has moved away from specific policy pledges to a more general sense of the desired direction of policy, the core of Europe has moved toward ever tighter monetary and fiscal policy coordination. To a large extent this divergence reflects the strong desire for political union in Europe, but it also reflects a greater commonality of economic philosophy within continental Europe than across the G-7.

However, even across the G-7 countries, there has been a convergence of economic understanding over time and the process of policy dialogue probably helped to advance this common understanding. In the 1990s, there was broad agreement on the need to reduce fiscal deficits in most countries and the desirability of giving central banks the primary goal of price stability. (Japan was the primary outlier, where it was agreed that both monetary and fiscal policy should focus on supporting growth.) Both Japan and the euro-area countries agreed on the need for structural reforms to increase competition and flexibility of financial, labor, and product markets. Monetary and fiscal policies moved in the agreed directions to a substantial, even surprising, extent, although progress on structural reforms was often disappointing.

In the field of currency intervention, most G-7 countries have come to perceive important limitations in the efficacy of such intervention as a policy tool and have been unwilling to engage in the really large operations that might be required to make this tool effective. ${ }^{41}$ This development has had the beneficial effect of reinforcing the focus of policy coordination on macroeconomic fundamentals. However, it is possible that intervention could play some role in the future if currencies moved sufficiently far from their perceived fundamentals.

It remains to be seen whether future opportunities for explicit policy deals may present themselves and how the G-7 will respond to such opportunities. There are reasons to believe that explicit deals will be harder to come by in the future. Countries

\footnotetext{
${ }^{41}$ Japan has been more willing to intervene regularly than other G-7 countries, but the magnitude of Japanese intervention, although increasing in recent years, continues to be modest relative to the size of the yen-dollar and yen-euro foreign exchange markets.
} 
(outside of the euro area) have been increasingly reluctant to make specific policy pledges due to the uncertain ability of at least some of the participants to persuade their legislatures to enact the required fiscal or structural legislation. Monetary authorities have become less willing to tie their hands in a public forum both out of concern about appearing to jeopardize their independence from governments and because they prefer to be able to react quickly to incoming news. Indeed the modern consensus that central banks should be independent and focused solely on macroeconomic stabilization primarily price stabilization - has greatly reduced the attention on monetary policy in the context of the G-7. ${ }^{42}$ Consequently, fiscal and structural policies have received greater emphasis over time.

Despite the potential existence of policy tradeoffs, trade negotiations have rarely played a role in macroeconomic policy coordination. ${ }^{43}$ This is probably due to the slow and complicated nature of trade discussions and the glacial speed with which they are implemented. Nevertheless, there may be scope for incorporating trade policy as one element of the policy coordination dialogue, especially given the attention already devoted to current account imbalances.

From the point of view of each country's own output and inflation objectives, the 1990s outcomes were considered largely successful in terms of what macroeconomic policies can do, although European and Japanese policy makers admitted that earlier structural reforms would have led to higher growth rates. Some U.S. policy makers believed that macro policies could have yielded higher growth in Europe and Japan, but the level of concern was lower than at times in previous decades. All sides viewed the current account imbalances between the three regions as a major problem. Given the difficulty of achieving internal political consensus on major fiscal and structural policy agendas, it seems unlikely that international policy coordination could have accomplished more on these fronts.

\section{Correspondence between Models and Experience: Some Lessons}

\section{IV.A Where Have the Models and Experience Coincided Well?}

\footnotetext{
${ }^{42}$ Central bank governors meet monthly at the BIS, providing a forum for cooperation in which they can maintain their independence from their respective governments. However, even in this forum, there has been a reluctance to commit to specific policy "deals," and the discussion has been primarily of the information-sharing type. This reluctance presumably stems from the desire to retain maximum freedom to maneuver rapidly in response to news. Building a consensus for specific coordinated policies is likely to take longer than a single meeting, so that even with monthly meetings coordinated policy making would be much slower than most central banks are willing to accept.

${ }^{43}$ The 1978 Bonn summit was the primary exception. Since then, G-7 statements have routinely noted the importance of maintaining an open and free trading system, but have not pledged specific trade policy changes.
} 
The central insight of the modeling literature is that when each country's policies generate externalities on other countries' welfare, there will be gains from international policy coordination. As we have seen, taking account of externalities does appear to be a major factor behind international coordination history, from the initial response to the 1973 oil price shock, through the Bonn Agreement of 1978, attempts to deal with external imbalances of the 1980s and 1990s, and the formation of monetary union within Europe.

Experience has generated examples of economic shocks that can be fairly characterized according to the standard categories of symmetric, asymmetric, and idiosyncratic shocks. Various oil shocks can be viewed as approximately symmetric shocks from the point of view of the industrial countries. Undesirably high inflation rates in European countries in the early 1980 s can be viewed as approximately symmetric shifts in initial conditions (resulting from past shocks and mistaken policy responses). The fiscal expansion in the United States and fiscal contraction in Europe and Japan in the early 1980s can be viewed as an asymmetric fiscal policy shock, at least from the point of view of monetary authorities that were forced to respond to it. German reunification is a classic example of a country-specific shock.

The models have focused on macroeconomic policy coordination, and this area has received the most attention historically, especially within Europe. However, other areas, such as structural policies, have received increased attention over time. Indeed, some of the most interesting episodes of international policy coordination in the 1990s have occurred in non-macroeconomic areas such as responding to financial crises and providing debt relief to poor countries. These are areas where cooperation is important because of externalities and the "free rider" problem. To an individual creditor, debt relief mainly benefits other creditors, so joint action is needed in order to help the debtor. More generally, policy makers within the G-7 and within the EU have never felt constrained as to the areas of policy that can usefully be coordinated and that is probably a good thing.

\section{IV.B Where Have the Models and Experience Not Coincided Well?}

\section{IV.B.1 Treatment of Exchange Rates and Current Account Balances}

In most of the models of policy coordination, it is assumed that the policy maker in each country minimizes a loss function that depends on the output gap and inflation. ${ }^{44}$ The current account and the exchange rate usually are not included in the loss function. The focus of the analysis is how to choose monetary policy (and sometimes also fiscal policy) in the two countries to achieve the best possible outcomes for the output gap and inflation.

\footnotetext{
${ }^{44}$ The most common functional form is a weighted sum of squared deviations of output from potential output and squared deviations of inflation from a target value.
} 
However, in international meetings of macroeconomic policy makers, much time is spent discussing the appropriateness of current account and exchange rate developments and what should be done to attempt to influence them if they are judged to be inappropriate. There are several possible reasons why so much time is spent discussing current account and exchange rate developments in international fora.

- $\quad$ First, external variables are obviously legitimate topics for discussion in such fora, as they constitute the transmission channel by which one country's policies affect other countries. Some countries may find it more expedient to cast international policy coordination in terms of these variables than in terms of internal variables such as the output gap and inflation rate.

- $\quad$ Second, current accounts and exchange rates can be regarded as information variables or indicators of the appropriateness of macroeconomic policies given the current shocks even if they are not target variables.

- $\quad$ Third, for some countries, exchange rate depreciations can lead to immediate and substantial upward pressures on inflation.

- $\quad$ Fourth, foreign exchange markets may be subject to inappropriate and irrational movements, and these markets may be susceptible to influence by the public statements of macroeconomic policy makers.

- $\quad$ Finally, the current account may actually be a target variable along with the output gap and inflation.

Indeed, the record of official statements over the years leaves the strong impression that policy makers view non-zero current account balances, and the large exchange rate movements that often precede current account imbalances, as undesirable per se. There are two main reasons why policy makers may take this view. First, sharp swings in current accounts produce dislocations and incur adjustment costs, and these costs are viewed as especially pernicious if the current account is expected to be reversed in the near future. Second, current account imbalances may give rise to protectionist pressures in deficit countries that could threaten global free trade.

However, it is important to recognize that current account imbalances often redirect demand from overheated to stagnant economies and improve macro outcomes globally. Moreover, the capital flows associated with current account imbalances are the mechanism by which rates of return are equalized across countries, leading to a more efficient global allocation of capital.

A possible example of a beneficial current account imbalance is the present situation in which the United States is experiencing a large positive productivity shock. It may be appropriate for there to be a large swing in the real value of the dollar and the U.S. current account, as the United States borrows abroad now to finance investment and consumption justified by the productivity increase, but later must service the increase in debt out of future earnings on the (more productive) capital stock.

In some cases, a current account imbalance may signal an inappropriate policy mix, even though the imbalance itself is beneficial given the policy mix in place. One 
example is the early 1980s when there was fiscal expansion in the United States and fiscal contraction in many of the other OECD countries. While it might have been best if the U.S. fiscal expansion had never taken place, it seems clear that given the paths of fiscal policies, the monetary policies chosen (which implied large swings in the real value of the dollar and the U.S. current account deficit) were more appropriate than a looser monetary policy in the United States and tighter monetary policies abroad (which would have implied smaller swings). The current account deficit enabled the United States to maintain a relatively stable path of output and prices without sacrificing investment in future productivity.

Finally, an example of an undesirable current account imbalance is one caused by financial market irrationality that propels a country's exchange rate far from its fundamental equilibrium. In such a case, capital is mis-allocated and trade adjustment costs are wasted because the exchange rate, and hence the current account, are not in equilibrium. This example provides the best case for currency intervention to offset exchange rate swings.

The case for policy action is strongest when the current account imbalance is unsustainable in the sense that the implied future changes in international asset portfolios are implausibly large. Unsustainable imbalances can arise either because of large structural fiscal deficits or because of a long-lasting asset market disequilibrium. By definition, unsustainable imbalances cannot persist indefinitely. The mechanism by which they eventually end is typically a sharp change in the exchange rate. Policy action to address the fundamental source of the imbalance at an early stage can help to minimize the disruption that would be caused by a sharp change later on.

Unfortunately, it is not easy to know when a given current account imbalance is unsustainable. In light of the persistence of what were thought to be unsustainable imbalances between the United States, Japan, and Europe for the better part of two decades, and given the lack of any significant return to protectionism, perhaps policy makers need to reconsider the attention devoted to minimizing current account imbalances.

\section{IV.B.2 Role of Fiscal Policy in Stabilization}

In the model literature of the 1980s and 1990s on stabilization conflicts, attention was focused primarily on monetary policy. It was usual to regard fiscal policy as one of the givens to which monetary policy had to react. Why fiscal policy was almost completely discounted as a stabilization tool is not completely clear, but there are several possible reasons.

- $\quad$ First, fiscal policy played an important role in stabilization policy in the $1960 \mathrm{~s}$ and 1970s and may have suffered disproportionately from the general disillusionment with stabilization policy in the 1980s and 1990s, when it was referred to pejoratively as "fine tuning." 
- Second, it has been argued that fiscal policy cannot be changed in a timely enough fashion for it to be effective in responding to changing macroeconomic conditions.

- $\quad$ Third, temporary tax changes may have only a small effect on stabilizing output.

- $\quad$ Fourth, for political reasons, fiscal policy may focus on long-term goals, such as

the Reagan Administration's desire to secure higher potential output from supplyside tax cuts.

Several considerations suggest that it may be time to reevaluate the presumption that fiscal policy is not useful as stabilization tool.

- $\quad$ First, while it may be difficult to change fiscal policy in a timely fashion in the United States, it is not as difficult to so do in the parliamentary systems of the other major industrial countries. Moreover, it may be possibly to design more "automatic stabilizers" that do not require ad hoc legislative action.

- $\quad$ Second, even if fiscal policy changes take longer to achieve than monetary policy changes, fiscal policy may affect the economy with a shorter lag.

- $\quad$ Third, when economic activity is weak and short-term interest rates reach a zero lower bound, as they have in Japan, it may be appropriate for fiscal policy to play an increased role in stimulating economic activity.

- $\quad$ Finally, with the inception of EMU, the member countries have no scope for using monetary policy to deal with stabilization conflicts caused by asymmetric or country-specific shocks, so it may be desirable to rely more heavily on fiscal policy.

\section{IV.B.3 Non-Optimal Policies}

While the models typically consider that ongoing conflicts arise from inconsistent objectives between two countries, in practice misguided policies are more often the source of ongoing conflict. A recent example was the persistence of high fiscal deficits in many countries long after policy makers realized that these deficits were not optimal even in the absence of harmful externalities across countries. Indeed, it may be argued that persistent and misguided fiscal policies were the fundamental issue behind most of the practical coordination dialogue in the 1980s and 1990s, since they often are the major source of large swings in exchange rates and current account balances.

In this vein, some critics of policy coordination have argued that there are much bigger gains to be had from countries moving to the frontier of their own optimal policy set (without coordination) than from there to a coordinated outcome. ${ }^{45}$ This follows simply from the quantitative model work, where the gains to policy coordination are typically relatively modest. Feldstein (1988) claims that based on his experience in the Reagan Administration, policy coordination sometimes distracts policy makers from necessary domestic policy responses and sometimes the policies under discussion would have a harmful or negligible effect on the economy. The actions of other governments

\footnotetext{
${ }^{45}$ See, for example, Fischer (1988) and Feldstein (1988).
} 
may become the scapegoat for one's own inability to take actions at home. He and others further note that policy coordination may be very difficult to do because of domestic political constraints, either because of political considerations or because "government" is not a single agent but rather several bodies having responsibilities over different areas of policy (more on this issue below).

\section{IV.B.4 Internal Political Dynamics}

It is clear from the historical record that no policy dialogue has persuaded a country to undertake a policy shift unless a significant constituency for that shift already existed within the country. The modeling literature would benefit from greater attention to the interaction between internal and external policy dialogues. While the literature has explored the issue of enforcement of international agreements, it has tended to do so from the point of view of a single agent who is tempted to cheat on his agreement. In practice, however, the parties negotiating an international agreement have almost always made a good faith effort to live up to their commitments. The difficulty is typically in obtaining the necessary internal approval to implement the external agreement.

\section{IV.B.5 Information Exchange}

In all of the various fora for international economic policy coordination, probably the most consistent activity is information exchange, both concerning the perceived state of the world and the internal policy debate within each country. This helps to ensure that policy makers are fully informed. To the extent that the group compares the record of past discussions with actual economic outcomes, it can provide a "reality check" both on whether policy makers do as they say they will do and on whether their models of the world make sense.

The literature on model uncertainty and information sharing provides interesting insights on when such activities would be expected to be welfare improving and when they might not be. In practice, behavior such as willful provision of misinformation is not realistic since almost all data becomes public eventually and most data becomes available to everyone at the same time. Similarly, it is highly unlikely that policy makers could convincingly deceive one another about their objectives or their internal models of the economy. In practice, the dialogue is one of education and moving toward a more common understanding of the international economy.

\section{IV.B.6 Monetary Policy Coordination}

As noted previously in this paper, stabilization models of international macroeconomic policy coordination generally have focused upon monetary policy coordination, with fiscal policy generally being characterized as one of the elements in the central banks' policy environment. Yet, as also noted earlier, there have been relatively few episodes of overt and explicit monetary policy coordination since the passing of the Bretton Woods system, and particularly in recent years, monetary authorities have been reluctant to commit to concrete, publically announced plans of 
action. Given that monetary policy actions in one country can generate externalities for other countries, what accounts for the relative paucity of international agreements on monetary policy outside of Europe? There are several explanations that might answer this question to some extent.

- $\quad$ First, central banks zealously guard their independence, and entering into international policy commitments either entails, or might be perceived by the public to entail, a loss of that independence. While it is true that central bank independence generally is defined as independence from the government or the finance ministry, some central banks may view any commitment of their policies to an external party as infringing on their prerogatives and responsibilities.

- $\quad$ Second, in a rapidly changing economic environment, commitments to future monetary policy actions may be undesirable or infeasible.

- $\quad$ Third, relative to the overall volatility of the economic environment, the externalities for one country associated with a monetary policy action in a second country may be relatively small. It may be only in the face of particularly large shocks - such as the oil price shocks of the 1970s - that the gains to coordination become sufficiently large to merit the effort required to achieve them.

The considerations listed above imply that international monetary policy coordination on the global level, to the extent that it occurs, probably is implemented in a more subtle and less overt fashion than is contemplated in at least the simplest of the policy coordination models. While monetary policy makers rarely reach explicit public agreement on how their monetary policies should be determined, in the course of frequent meetings in which their countries' economic situations and monetary stances are discussed, informal consensuses may evolve concerning the direction of policy and the appropriate responses to shocks going forward.

For example, at present, many industrial-country monetary authorities are in a tightening posture as efforts are made to ensure that strengthening activity and the stillhigh level of oil prices are not reflected in sustained gains to inflation. In principle, this situation could lead to a tighter-than-optimal stance of global monetary policy as tightening in each country, through its effects on exchange rates, prompts additional tightening in the other countries. In practice, this situation will not likely lead to a formal agreement on monetary policy coordination, but it may lead to an informal consensus that tightening should proceed tentatively and with the prospective reactions of other central banks in mind as well. This informal consensus can be monitored on a frequent basis, insofar as the discussion at international meetings could highlight unfavorably the actions of countries not adhering to this consensus.

Hence, in practice, monetary policy coordination might be hard to distinguish from the information exchange process described in IV.B.5 above. Or, to put it another way, the information being exchanged is (1) a description of the current and prospective reaction functions adhered to by the different national monetary authorities, and (2) views on the appropriate reaction functions to implement moving forward. This type of exchange is sufficiently subtle, private, and non-binding to satisfy the central banks' need 
for independence and scope to address unexpected contingencies, and yet at the same time may accomplish much of the coordination required in order to exploit policy externalities.

It is interesting to note that the formation of the euro area addresses some of the same concerns described above (central bank independence, freedom to maneuver, and externalities) in a very different manner. First, the independence of the new ECB is enshrined in the Maastricht Treaty, which cannot be changed by a simple majority of the European Parliament or any national parliament. Second, the problem of reaching explicit agreement without losing the ability to respond quickly to new developments is solved by imposing an integrated institutional structure, known as the European System of Central Banks, onto the existing national central banks of member countries, with the ECB as the headquarters. Finally, the externalities associated with independent monetary policies within the euro area are generally greater than the externalities across G-7 countries, due to the very close economic linkages within Europe.

\section{IV.B.7 Exchange Rate Target Zones}

Some modelers have argued for exchange rate target zones as a mechanism for enforcing macroeconomic policy coordination. If target zones are viewed as a variant of fixed exchange rates, then they can lead to better outcomes in the case of symmetric shocks. However, in the case of asymmetric or country-specific shocks, the optimal policy response generally will involve movements in exchange rates. Proponents of target zones argue that the limited flexibility of exchange rates within the zones provides some cushion in the case of asymmetric or country-specific shocks, and that countries could agree to alter the zones in the event of a sufficiently large asymmetric or countryspecific shock. However, if altering the zones in response to shocks is a recurrent option, it is not clear what benefit is gained by having zones in the first place.

The experience of Europe - a relatively integrated and homogeneous area - with different exchange rate regimes casts severe doubt on the practicality of target zones across the G-7 countries. Dissatisfaction with experience under the target zone systems of the snake and the ERM led European countries to engage in increasingly close monetary and fiscal coordination culminating in monetary union last year. Such explicit and restrictive institutional links are highly improbable among the other G-7 countries. Even if they were politically feasible, economic shocks across the G-7 countries are far less symmetric than among the countries of the euro area.

\section{Conclusions}

\section{V.A What Have We Learned?}

Based on the foregoing analysis of both models of, and experience with, international macroeconomic policy coordination, we would like to point out some areas where modelers could devote further efforts most fruitfully and where policy makers could learn from both the insights of the models and the historical experience. 
Areas for further modeling effort:

- Practical policy coordination almost always involves more than one type of policy, and usually involves several types of policies. At a minimum, more effort should be devoted to joint modeling of monetary and fiscal policies.

- Internal political divisions within countries have a major impact on the international coordination process. Macro policy modelers should draw from models in microeconomic areas that have considered the impact of internal factions on the cross-country coordination process.

- $\quad$ Modeling the process of information exchange is still in its early stages and could yield a large payoff since information exchange is the most universal feature of practical policy coordination.

- $\quad$ Economic modelers in general have not fully explored the implications of market irrationality and bubbles for both internal and external policies.

Issues for policy makers:

- $\quad$ Policy makers should think carefully about their ultimate objectives. In particular, should the current account be considered an objective, and, if so, should the target for the current account always be zero?

- International coordination will be more relevant and productive if policy makers can achieve better internal policies first, as inappropriate domestic policies have sometimes become the main focus of international policy discussions. In particular, a structural fiscal deficit is often responsible for an overvalued currency and a persistent current account deficit.

- $\quad$ Policy makers may have discounted the role of fiscal policy in stabilization too much because past attempts to use it led to unsustainable budget deficits. Rather than ignore fiscal policy as a stabilization tool, perhaps there should be more effort toward designing a sustainable framework for counter-cyclical fiscal policy, at least in those countries where the fiscal process allows a sufficiently timely response to shocks.

So is policy coordination among the developed countries alive in the new millennium? First, it is clear that information exchange is very active, perhaps even to excess. There are many opportunities for such exchanges and much time consumed by government officials (and their staffs) in preparing for and traveling to these meetings. As we suggested earlier, particularly in the case of monetary policies, such exchanges can lead to an implicit form of policy coordination in the context of repeated interactions. In addition, information exchange helps policy makers to advance to a more common understanding of the global economy.

Second, the move in the euro area to a single currency, to a supranational central bank, and to binding guidelines on fiscal policies have taken policy coordination to a new level. 
Third, policy coordination in the G-7 has evolved in at least two ways. There is less focus on specific policy agreements and more on the general direction of policy in the G-7 countries. This reflects domestic political constraints in being able to deliver very specific policy commitments. And there has also been less willingness to participate in coordinated intervention and more attention to the fundamental policies that may be the source of undesired swings in exchange rates and current account balances. In general, the focus has been to achieve cyclical convergence among the G-7 economies to minimize swings in exchange rates and current accounts and to encourage policy mixes within countries that also contribute to that objective.

\section{V.B Coordination Issues Today}

In the past few years, there has been an unusually wide divergence in the cyclical positions of the G-7 economies - with U.S. growth surprisingly robust, Japan exceptionally weak, and the euro area in between. This is an example of a "stabilization problem," though an unusually persistent one. In effect, it also represents initial conditions that have the effect of asymmetric shocks. This disparity has been the source of recent swings in exchange rates and current account balances. The latter developments are desirable in response to the cyclical divergence--in effect, open economy versions of built-in stabilizers - but cyclical convergence, achieved with an appropriate mix of policies, could reduce the swings in exchange rates and current account balances. In moving toward cyclical convergence, the emphasis has therefore been on policy choices that at least would not themselves widen the swings in exchange rates and current accounts. With respect to Japan, that meant an emphasis on fiscal policy and domesticdemand led growth, as oppose to policies that relied on currency depreciation and external stimulus. This is a perfect example of avoiding negative externalities. With respect to the United States, there has been some emphasis on holding onto the budget surpluses - both to avoid further stimulus to demand and to avoid further deterioration in the current account.

A second issue is the G-7 response to the global financial turmoil and crises among emerging market economies - in effect, a symmetric shock to the G-7 economies. From the standpoint of macro policy, the key has been to ensure that aggregate demand in the G-7 was maintained in order to be a stabilizing force in the global economy. While this was primarily an issue of each country/area responding to domestic stabilization needs, there was a focus as well on ensuring that the policy choices within the G-7 did not increase G-7 growth at the expense of other economies.

A third important issue is the productivity shock. The question here is what kind of a shock this is - a country-specific shock or a symmetric shock? At the moment it appears to be a country-specific shock and as a result has added secular divergence to the remaining cyclical divergence, further feeding, for a while, both the appreciation of the dollar and the widening of the U.S. current account deficit. If this turns out to be a symmetric shock, with productivity picking up over time elsewhere, the effects on exchange rates, capital flows and current accounts will presumably unwind. There has been some attention in G-7 discussions to focusing on structural reforms in the euro area 
and Japan that might strengthen sustainable growth rates in those areas, reducing the prevailing secular divergence.

A fourth issue is the weakness in the euro. To a degree the depreciation of the euro has reflected the cyclical and secular disparities discussed above and to some extent may have been reinforced by the unexpected strength of euro liability issue. But many believe that the depreciation in the euro is greater than can be accounted for by fundamentals, making it a topic of G-7 rhetoric, at least.

A fifth issue - which has received relatively little attention in the G-7 - is the sharp rise in oil prices in 1999 and into early 2000. This is another example of a symmetric shock to the G-7 economies that potentially could call for calibrated responses, in light of the changes in each country's policies. However, in part because this was a rebound from a level that was not perceived as sustainable and because of the reduced vulnerability of G-7 economies to changes in oil prices, there has been relatively little focus on this shock. 


\section{Appendix A: Outcomes in a Two-Country Model with Both Monetary and Fiscal Policy}

Consider a one-shot game in a standard model with two countries, unstarred and starred, in which each country has employment and CPI inflation as objectives and has both monetary and fiscal policies as instruments. For shocks to money or goods demands both countries can attain bliss, but for productivity shocks no Nash noncooperative equilibrium exists. All variables (except interest rates) are natural logarithms. Variables with bars over them represent natural values. Natural values of employments are inelastic notional supplies, and natural values of all other variables, are zero-disturbance, flexible wage values. Let variables with hats over them represent deviations of variables from their natural values.

Production functions imply that outputs, $y$ and $y^{*}$, rise with the employments, $n$ and $n^{*}$, and fall with the productivity shocks, $x$ and $x^{*}$, so

$$
\hat{y}=(1-\alpha) \hat{n}-x, \quad \hat{y}^{*}=(1-\alpha) \hat{n}^{*}-x^{*}
$$

Nominal wages minus output prices, $p$ or $p^{*}$, must equal marginal products of labor. Since nominal wages are set at their zero-disturbance, flexible-wage value, rearranging yields

$$
\hat{p}=\alpha \hat{n}+x, \quad \hat{p}^{*}=\alpha \hat{n}^{*}+x *
$$

Consumer price indices, $q$ and $q^{*}$, and the real exchange rate, $z$, in deviation form are

$$
\hat{q}=\hat{p}+\beta \hat{z}, \quad \hat{q}^{*}=\hat{p}^{*}-\beta \hat{z}, \quad \hat{z}=\hat{e}+\hat{p}^{*}-\hat{p}
$$

where $\beta$ is the common propensity to import, and $e$ is the nominal exchange rate.

Outputs must equal demands. Unstarred (starred) demand rises with outputs and unstarred (starred) government expenditures net of a demand shock, $g\left(g^{*}\right)$, falls with real interest rates, $r$ and $r^{*}$, and rises (falls) with real depreciation of the unstarred currency:

$$
\begin{aligned}
& \hat{y}=(1-\beta) \varepsilon \hat{y}+\beta \varepsilon \hat{y}^{*}-(1-\beta) v \hat{r}-\beta \hat{v}^{*}+\delta \hat{z}+\hat{g} \\
& \hat{y}^{*}=\beta \varepsilon \hat{y}+(1-\beta) \varepsilon \hat{y}^{*}-\beta v \hat{r}-(1-\beta) v \hat{r}^{*}-\delta \hat{z}+\hat{g}^{*}
\end{aligned}
$$

Money supplies net of money demand shocks, $m$ or $m^{*}$, must equal money demands which rise with outputs and output prices and fall with nominal interest rates, $i$ or $i^{*}$; furthermore, open interest parity and Fisher equations hold:

$$
\begin{aligned}
& \hat{m}=\hat{p}+\hat{y}-\lambda \hat{i}, \quad \hat{m}^{*}=\hat{p}^{*}+\hat{y}^{*}-\lambda \hat{i}^{*} \\
& \hat{i}=\hat{i}^{*}-\hat{e}, \quad \hat{i}=\hat{r}-\hat{q}, \quad \hat{i}^{*}=\hat{r}^{*}-\hat{q}^{*}
\end{aligned}
$$

The reduced form for employments and the real exchange rate are ${ }^{46}$

${ }^{46}$ The coefficients of the reduced forms are

$$
\begin{gathered}
\Delta \psi_{1}=\theta_{1}\left(\theta_{5}-\theta_{6}\right)+\theta_{2} \theta_{5}>0, \Delta \psi_{2}=\theta_{1} \theta_{6}+\theta_{2} \theta_{5} \frac{\geq}{<} 0, \Delta \psi_{3}=\theta_{1}+\theta_{2}>0, \Delta \psi_{4}=\theta_{2}, \\
\Delta \psi_{5}=\theta_{1}\left(\theta_{3}+\theta_{4}\right)+\theta_{2} \theta_{3}, \Delta \psi_{6}=\theta_{2} \theta_{3}-\theta_{1} \theta_{4}, \Delta \psi_{7}=\theta_{1}\left[\frac{1}{\lambda}\left(\theta_{1}+\theta_{2}\right)+\gamma\left(2 \theta_{6}-\theta_{5}\right)\right]>0, \\
\Delta \psi_{8}=\Delta \theta_{1}\left[1+2 \theta_{2}-\gamma\left(\theta_{3}+2 \theta_{4}\right)\right] \Delta=\theta_{1}^{2}+2 \theta_{1} \theta_{2}>0, \theta_{1}=(1-\varepsilon)(1-\alpha)+\gamma \delta, \theta_{2}=\beta \varepsilon(1-\alpha)-\kappa \gamma, \\
\theta_{3}=1-\varepsilon+v, \theta_{4}=\beta \varepsilon+\kappa, \theta_{5}=\frac{\nu-\kappa}{\lambda}, \theta_{6}=\frac{\kappa}{\lambda}, \kappa=2 \beta(1-\beta) \nu-\delta, \gamma=\alpha+\frac{1}{\lambda}
\end{gathered}
$$




$$
\begin{gathered}
\hat{n}=\psi_{1} \hat{m}+\psi_{2} \hat{m}^{*}+\psi_{3} \hat{g}+\psi_{4} \hat{g}^{*}+\psi_{5} x+\psi_{6} x^{*} \\
\hat{n}^{*}=\psi_{2} \hat{m}+\psi_{1} \hat{m}^{*}+\psi_{4} \hat{g}+\psi_{3} \hat{g}^{*}+\psi_{6} x+\psi_{5} x^{*} \\
\hat{z}=\psi_{7}\left(\hat{m}-\hat{m}^{*}\right)-\gamma \psi_{3}\left(\hat{g}-\hat{g}^{*}\right)+\psi_{8}\left(x-x^{*}\right)
\end{gathered}
$$

The reduced forms for $\hat{q}$ and $\hat{q}^{*}$ can be obtained using equations (3), (2), and (6).

Each government seeks to minimize a loss function,

$$
L=\frac{1}{2}\left[\sigma(k-\hat{n})^{2}+\left(\hat{q}+\bar{q}-q_{-1}\right)^{2}\right], \quad L^{*}=\frac{1}{2}\left[-\sigma\left(k-\hat{n}^{*}\right)^{2}+\left(\hat{q}^{*}+\bar{q}^{*}-q^{*}{ }_{-1}\right)^{2}\right]
$$

where the target value of employment is greater than or equal to the natural rate if $k \geq 0$, and the target values for CPI inflation rates are zero.

When $k=0$, the first order conditions with noncooperative behavior are a system of four equations in the three variables, $n, n^{*}$, and $z$ which can be shown to be independent:

$$
\begin{aligned}
& \frac{\partial L}{\partial m}=\psi_{1} \sigma \hat{n}+\left(\alpha \psi_{1}+\beta \psi_{7}\right)\left(\alpha \hat{n}+\beta \hat{z}+x+\bar{q}-q_{-1}\right)=0 \\
& \frac{\partial L}{\partial g}=\psi_{3} \sigma \hat{n}+\left(\alpha \psi_{3}-\gamma \psi_{3}\right)\left(\alpha \hat{n}+\beta \hat{z}+x+\bar{q}-q_{-1}\right)=0 \\
& \frac{\partial L^{*}}{\partial m^{*}}=\psi_{1} \sigma \hat{n}^{*}+\left(\alpha \psi_{1}-\beta \psi_{7}\right)\left(\alpha \hat{n} *-\beta \hat{z}+x^{*}+\bar{q}^{*}-q^{*}{ }_{-1}\right)=0 \\
& \frac{\partial L^{*}}{\partial g^{*}}=\psi_{3} \sigma \hat{n}^{*}+\left(\alpha \psi_{3}+\gamma \psi_{3}\right)\left(\alpha \hat{n} *-\beta \hat{z}+x^{*}+\bar{q}^{*}-q^{*}{ }_{-1}\right)=0
\end{aligned}
$$

With no productivity shocks $\left(x=x^{*}=0\right)$, there is a Nash equilibrium and bliss can be attained. The natural money supplies, $\bar{m}$ and $\bar{m} *$, are set so that $\bar{q}=q_{-1}$ and $\bar{q}^{*}=q^{*}{ }_{-1}$. In this situation, the system of equations (8) is homogenous and, thus, is satisfied by $\hat{n}=\hat{n}^{*}=\hat{z}=0$. From equations (2) and (3) it follows that $\hat{p}=\hat{p}^{*}=0$ and $\hat{q}=\hat{q}^{*}=0$, so bliss is attained. However, with productivity shocks, there is no Nash equilibrium. The system of equations (8) is not homogenous and, therefore, has no solution. These conclusions follow whether or not there are money demand and goods demand shocks.

When $k \geq 0, \psi_{2}=0$, and disturbances are zero so that the deviations of all variables from their natural levels are zero, the first order conditions for the unstarred country with noncooperative behavior and with joint maximization are, respectively,

$$
\begin{aligned}
& \frac{\partial L}{\partial m}=\left[-\sigma k \psi_{1}+\left(\bar{q}-q_{-1}\right)\left(\alpha \psi_{1}+\beta \psi_{7}\right)\right]=0 \\
& \frac{\partial\left(L+L^{*}\right)}{\partial m}=\left[-\sigma k \psi_{1}+\left(\bar{q}-q_{-1}\right)\left(\alpha \psi_{1}+\beta \psi_{7}\right)\right]-\left(\bar{q} *-q^{*}{ }_{-1}\right)\left(\beta \psi_{7}\right)=0
\end{aligned}
$$

Since the two countries are symmetric, in equilibrium $\bar{q}-q_{-1}=\bar{q}^{*}-q^{*}{ }_{-1}$. Therefore, with joint maximization, the natural money supply $\bar{m}$ must be set so that $\bar{q}-q_{-1}$ is greater and inflation bias is higher. An analogous argument applies to $\bar{m}^{*}$ and $\bar{q} * q_{-1}^{*}$. 


\section{Appendix B: Chronology of International Macroeconomic Policy Coordination}

1940s Establishment of IMF to administer fixed exchange rate system.

Marshall Plan administered by the Organization for European Economic Cooperation, predecessor of the OECD. European Payments Union facilitates intra-European trade.

1950s IMF is locus of macro policy discussion.

European Coal and Steel Community established in 1952 and evolved into European Economic Community in 1958 (Treaty of Rome).

1962 Foundation of the General Arrangements to Borrow (GAB) and the G-10 to supplement IMF resources. Working Party Three begins a process of dialogue about balance of payments developments among the G-10 countries at the OECD.

1970 Werner Report outlines path to European Economic and Monetary Union.

1971-72 Repeated negotiations (including Smithsonian Agreement of 1971) to salvage fixed exchange rates.

In 1972, six EC countries plus Denmark and the United Kingdom join currency "snake." The United Kingdom and Italy leave the snake within a year.

1973 Finance ministers of the United States, France, Germany, and the United Kingdom (the Library Group) meet in the White House library. The G-5 (adding Japan) finance ministers and central bank governors process begins later in the year.

United Kingdom joins EEC.

1974 The G-5 spearhead collective response to oil shock. Launch oil adjustment facility at the IMF. Establish IEA.

France drops out of snake.

1975 Giscard and Schmidt (original Library Group members) decide to elevate the G-5 process to the Head of State level and add Italy at the Rambouillet summit.

France rejoins snake.

1976 Canada attends the summit in Puerto Rico to form the G-7, but ministerial process remains the G-5. 
France drops out of snake.

1977 President of European Commission attends London summit. G-3 countries adopt unspecified, but widely acknowledged, growth targets.

1978 Bonn summit trades off U.S. oil price decontrol with fiscal expansion in Germany and Japan.

1979 France and Italy join the snake countries to form the ERM.

1980-84 Thatcher and Reagan administrations ideologically opposed to international coordination. Jurgensen Report (1983) questions effectiveness of sterilized intervention.

1985 Plaza Agreement aims to hasten dollar depreciation. Coordinated intervention. Single European Act drafted. The Act was ratified in 1986 and took effect in 1987.

1987 Louvre Accord aims to stabilize dollar. Italy and Canada become permanent members of G-7 ministerial process. Coordinated intervention.

1988-89 Frequent coordinated intervention in the face of continued currency volatility. Delors Report sets the stage for EMU.

1990-91 G-7 organizes payments for Gulf War.

German unification. United Kingdom joins ERM in 1990. Maastricht Treaty signed in 1991.

1992 United Kingdom and Italy forced out of ERM.

1993 ERM bands widened under pressure from speculative attack.

1994-99 Rising concern about Japanese recession and yen bubble. Agreement on need for fiscal consolidation in G-7 ex. Japan. General satisfaction on inflation.

EU Stability and Growth Pact agreed. ECB established and euro launched.

\section{Extant Fora}

Global: IMF, BIS, G-10, OECD (WP-3), G-7.

European: EU Commission, Ecofin, Euro-11 Council, ECB. 


\section{Appendix C: Some Regular International Policy Coordination Meetings (global level, excludes regional meetings)}

- G-7 Leaders' Summits: 1 per year

- $\quad$ G-7 Finance Ministers and CB Governors: 3 per year

- G-7 Deputy Finance Ministers: at least 1 before each FM/CBG meeting

- $\quad$ G-10 CB Governors at BIS: 10 per year

- G-10 Finance Ministers and CB Governors: 2 per year

- G-10 Deputy FMs and Deputy CBGs: 4 per year

- $\quad$ OECD Economic Policy Committee: 2 per year (sub-Deputy)

- $\quad$ OECD Working Party Three of EPC: 4 per year (Deputy/sub-Deputy)

- IMF International Monetary and Financial Committee: 2 per year (Ministerial)

- $\quad$ IMF Executive Board: at least weekly (sub-Deputy)

- $\quad$ BIS and OECD Expert-Level Meetings of Various Kinds 


\section{References}

Ainley, Michael (1984), “The General Arrangements to Borrow," Pamphlet Series No. 41, International Monetary Fund, Washington, DC.

Alesina, Alberto and Guido Tabellini (1987), "Rules and Discretion with Noncoordinated Monetary and Fiscal Policies," Economic Inquiry, 25 (October):619-630.

Bai, Hong and Stephen Hall (1996), "Testing the Symmetry of Shocks amongst the G3 Countries," Global Economic Institutions Working Paper 14, ESRC.

Basevi, G., F. Delbono, and V. Delnicolo (1990), "International Monetary Cooperation under Tariff Threat," Journal of International Economics, 28:1-23.

Becker, R., et. al. (1986), "Optimal Policy Design with Non-Linear Models," Journal of Economic Dynamics and Control, 10:27-31.

Bergsten C. Fred and C. Randall Henning (1996), Global Economic Leadership and the Group of Seven, Institute for International Economics, Washington, DC.

Bryant, Ralph (1995), International Coordination of National Stabilization Policies, Brookings Institution, Washington, DC.

Bryant, Ralph, Dale Henderson, Gerald Holtham, Peter Hooper, and Steven Symansky (1988), Empirical Macroeconomics for Interdependent Economies, The Brookings Institution, Washington, DC.

Bryant, Ralph, Peter Hooper and Catherine Mann (1993), Evaluating Policy Regimes: New Research in Empirical Macroeconomics, The Brookings Institution, Washington, DC.

Canzoneri, Matthew B. and Hali Edison (1990), "A New Interpretation of the Coordination Problem and Its Empirical Significance," in Peter Hooper et al. (eds.), Financial Sectors in Open Economies: Empirical Analysis and Policy Issues, Board of Governors of the Federal Reserve System, Washington, DC, 399-436.

Canzoneri, Matthew B. and Dale Henderson (1991), Monetary Policy in Interdependent Economies: A Game Theoretic Approach, MIT Press, Cambridge, MA.

Canzoneri, Matthew and Patrick Minford (1989), "Policy Interdependence: Does Strategic Behavior Pay? An Empirical Investigation Using the Liverpool World Model," in Hodgman, Donald and Geoffrey Woods, eds., Macroeconomic Policy and Economic Interdependence, London: Macmillan Press, 158-179. 
Caporale, Guglielmo Maria, Michael Chui, Stephen Hall and Brian Henry (1998a), "Fiscal Consolidation: An Exercise in the Methodology of Coordination," Global Economic Institutions Working Paper 38, ESRC.

Caporale, Guglielmo Maria, Michael Chui, Stephen Hall and Brian Henry (1998b), "Evaluating the Gains to Cooperation in the G3," Global Economic Institutions Working Paper 39, ESRC.

Cooper, Richard, Barry Eichengreen, C. Randall Henning, Gerald Holtham, and Robert Putnam (1989), Can Nations Agree?: Issues in International Economic Cooperation, The Brookings Institution, Washington, DC.

Currie, David and Paul Levine (1993), Rules, Reputation and Macroeconomic Policy Coordination, Cambridge University Press, Cambridge, MA.

Currie, David, Paul Levine and Joseph Pearlman (1996a), "The Choice of 'Conservative Central Banker' in Open Economies: Monetary Regime Options for Europe," Economic Journal, 106 (March):345-358.

Currie, David, Paul Levine and Joseph Pearlman (1996b), "Can Delegation Be Counterproductive? The Choice of 'Conservative' Bankers in Open Economies," Global Economic Institutions Working Paper 13, ESRC.

Dobson, Wendy (1991), “Economic Policy Coordination: Requiem or Prologue?” Policy Analyses in International Economics 30, Institute for International Economics, Washington, DC.

Eichengreen, Barry and Fabio Ghironi (1999), "Macroeconomic Tradeoffs in the United States and Europe: Fiscal Distortions and the International Monetary Regime," mimeo, Federal Reserve Bank of New York, (November).

Farrell, Joseph and Matthew Rabin (1996), "Cheap Talk," Journal of Economic Perspectives, 10, 3(Summer):103-118.

Feenstra, Robert C. (1992), "How Costly is Protectionism?" Journal of Economic Perspectives, 6 (Summer):159-178.

Feldstein, Martin (1988), "Distinguish Lecture on Economics in Government: Thinking about International Economic Coordination," Journal of Economic Perspectives, 2 (Spring):3-13.

Fischer, Stanley (1988), "International Macroeconomic Policy Coordination," in Martin Feldstein (ed.), International Economic Cooperation, NBER, University of Chicago Press, Chicago, IL. 
Ghosh, Atish and Paul Masson (1994), Economic Cooperation in an Uncertain World, Blackwell Publishers, Oxford, UK.

Hajnal, Peter I. (1999), The G7/G8 System: Evolution, Role and Documentation, Ashgate, Aldershot, UK.

Hamada, Koichi (1974), “Alternative Exchange Rate Systems and the Interdependence of Monetary Policies," in Robert Aliber (ed.), National Monetary Policies and the International Financial System, University of Chicago Press, Chicago, IL.

Hamada, Koichi (1976), “A Strategic Analysis for Monetary Interdependence,” Journal of Political Economy, 84:677-700.

Hamada, Koichi (1979), "Macroeconomic Strategy Coordination under Alternative Exchange Rates," in Rudiger Dornbusch and Jacob Frenkel (eds.), International Economic Policy, John Hopkins University Press, Baltimore, MD.

Hamada, Koichi (1985), The Political Economy of International Monetary Interdependence, MIT Press, Cambridge, MA.

Hamada, Koichi (1986), "Strategic Aspects of International Fiscal Interdependence," Economic Studies Quarterly, 37(June):165-180.

Hughes-Hallet, Andrew (1986), "International Policy Design and the Sustainability of Policy Bargains,” Journal of Economic Dynamics and Control, 10: 467-494.

James, Harold (1996), International Monetary Cooperation Since Bretton Woods, International Monetary Fund, Washington, DC.

Kenen, Peter B. (1996), The International Economy, Third Edition (with corrections), Cambridge University Press, Cambridge, UK.

Keohane, Robert O. (1984), After Hegemony: Cooperation and Discord in the World Political Economy, Princeton University, Princeton, NJ.

Levine, Paul and Joseph Pearlman (1997), "Delegation and Fiscal Policy in the Open Economy: More Bad News for Rogoff's Delegation Game," Global Economic Institutions Working Paper 25, ESRC.

McKibbin, Warwick (1997), "Empirical Evidence on International Economic Policy Coordination," in Michele U. Fratianni, Dominick Salvatore, and Jürgen von Hagen (eds.), Handbook of comparative economic policies, v. 5, Macroeconomic Policies in Open Economies, Greenwood Press, Westport, CT. 
McKibbin, Warwick J., and Jeffery D. Sachs (1988), "Coordination of Monetary and Fiscal Policies in the Industrial Economies," in Jacob Frenkel (ed.), International Aspects of Fiscal Policies, NBER, University of Chicago Press, Chicago, IL.

McKibbin, Warwick J., and Jeffery D. Sachs (1991), Global Linkages: Macroeconomic Interdependence and Cooperation in the World Economy, Brookings Institution, Washington, DC.

Obstfeld, Maurice and Kenneth S. Rogoff (2001, forthcoming), "Global Implications of Self-Oriented National Monetary Rules," Quarterly Journal of Economics.

Oudiz, Gilles and Jeffery Sachs (1984), "Macroeconomic Policy Coordination Among the Industrial Economies," Brookings Papers on Economic Activity, 1:1-64.

Oudiz, Gilles and Jeffrey Sachs (1985), "Intertemporal Policy Coordination in Dynamic Macroeconomic Models," in Willem Buiter and Richard Marston, eds., International Economic Policy Coordination, Cambridge University Press, Cambridge, UK.

Persson, Torsten and Guido Tabellini (1995), "Double-Edged Incentives: Institutions and Policy Coordination," in Kenneth S. Rogoff and Gene Grossman, Handbook of International Economics, North-Holland, Amsterdam, Netherlands.

Putnam, Robert D. and C. Randall Hennning (1989), "The Bonn Summit of 1978: A Case Study in Coordination," in Richard N. Cooper et al., eds., Can Nations Agree? Issues in International Economic Cooperation, Brookings Institution, Washington, DC.

Rogoff, Kenneth S. (1985a), "Can International Monetary Policy Coordination Be Counterproductive?” Journal of International Economics, 18:199-217.

Rogoff, Kenneth S. (1985b), "The Optimal Degree of Commitment to an Intermediate Monetary Target” Quarterly Journal of Economics, 100 (November):1169-1189.

Sachs, Jeffery and Warwick McKibbin (1985), "Macroeconomic Policies in the OECD and LDC External Adjustment," NBER Working Paper 1534.

Smyser, W.R. (1993) “Goodbye, G-7,” The Washington Quarterly, Winter: 15-28.

Solomon, Robert (1982), The International Monetary System, 1945-1981, Harper \& Row, New York, NY.

Solomon, Robert (1999), Money on the Move: The Revolution in International Finance Since 1980, Princeton University, Princeton, NJ.

Stark, Jürgen (1995), "The G7 At Work," The International Economy, September/October: 52-54. 
Tabellini, Guido (1990), "Domestic Policies and the International Coordination of Fiscal Policies," Journal of International Economics, 28:245-265.

The Twenty G7 Summits: On the Occasion of the Twentieth Summit, Naples, July 8/10, 1994 (1994), Adnkronos Libri, Rome, Italy.

Walsh, Carl (1995), "Optimal Contracts for Central Bankers," American Economic Review, 85 (March):150-167.

Whyman, William E. (1995), "We Can't Go On Meeting Like This: Revitalizing the G-7 Process," The Washington Quarterly, Summer: 139-165. 